Invited Synthesis Paper

\title{
Historical and Modern Disturbance Regimes, Stand Structures, and Landscape Dynamics in Piñon-Juniper Vegetation of the Western United States
}

\author{
William H. Romme, ${ }^{1}$ Craig D. Allen, ${ }^{2}$ John D. Bailey, ${ }^{3}$ William L. Baker, ${ }^{4}$ Brandon T. Bestelmeyer, ${ }^{5}$ \\ Peter M. Brown, ${ }^{1,6}$ Karen S. Eisenhart, ${ }^{7}$ M. Lisa Floyd, ${ }^{8}$ David W. Huffman, ${ }^{9}$ Brian F. Jacobs, ${ }^{1,10}$ \\ Richard F. Miller, ${ }^{11}$ Esteban H. Muldavin, ${ }^{12}$ Thomas W. Swetnam, ${ }^{13}$ \\ Robin J. Tausch, ${ }^{14}$ and Peter J. Weisberg ${ }^{15}$
}

\begin{abstract}
Authors are ${ }^{1}$ Professor, Department of Forest, Rangeland, and Watershed Stewardship, and Graduate Degree Program in Ecology, Colorado State University, Fort Collins, CO 80523, USA; ${ }^{2}$ Research Ecologist, US Geological Survey, Jemez Mountains Field Station, Los Alamos, NM 87544, USA; ${ }^{3}$ Associate Professor, Department of Forest Engineering, Resources and Management, Oregon State University, Corvallis, OR 97331, USA; ${ }^{4}$ Professor, Ecology Program and Department of Geography, University of Wyoming, Laramie, WY 82071, USA; ${ }^{5}$ Research Ecologist, US Department of Agriculture-Agricultural Research Service, Jornada Experimental Range, New Mexico State University, Las Cruces, NM 88003, USA; ${ }^{6}$ Director, Rocky Mountain Tree-Ring Research, Fort Collins, CO 80526, USA ${ }^{7}$ Assistant Professor, Department of Geosciences, Edinboro University of Pennsylvania, Edinboro, PA 16444, USA; ${ }^{8}$ Professor and Chair, Environmental Studies Program, Prescott College, Prescott, AZ 86303, USA; ${ }^{9}$ Research Associate, Ecological Restoration Institute, Northern Arizona University, Flagstaff, AZ 86011, USA; ${ }^{10}$ Vegetation Specialist, Bandelier National Monument, National Park Service, Los Alamos, NM 87544, USA; ${ }^{11}$ Professor, Department of Range Ecology and Management, Oregon State University, Corvallis, OR 97331, USA; ${ }^{12}$ Research Associate Professor, Natural Heritage New Mexico, University of New Mexico, Albuquerque, NM 87131, USA; ${ }^{13}$ Director and Professor, Laboratory of Tree Ring Research, University of Arizona, Tucson, AZ 85721, USA; ${ }^{14}$ Supervisory Range Scientist, US Department of Agriculture, Forest Service, Rocky Mountain Research Station, Reno, NV 89512, USA; and ${ }^{15}$ Assistant Professor, Department of Natural Resources and Environmental Science, University of Nevada, Reno, NV 89512, USA.
\end{abstract}

\begin{abstract}
Piñon-juniper is a major vegetation type in western North America. Effective management of these ecosystems has been hindered by inadequate understanding of 1 ) the variability in ecosystem structure and ecological processes that exists among the diverse combinations of piñons, junipers, and associated shrubs, herbs, and soil organisms; 2) the prehistoric and historic disturbance regimes; and 3) the mechanisms driving changes in vegetation structure and composition during the past $150 \mathrm{yr}$. This article summarizes what we know (and don't know) about three fundamentally different kinds of piñon-juniper vegetation. Persistent woodlands are found where local soils, climate, and disturbance regimes are favorable for piñon, juniper, or a mix of both; fires have always been infrequent in these woodlands. Piñon-juniper savannas are found where local soils and climate are suitable for both trees and grasses; it is logical that low-severity fires may have maintained low tree densities before disruption of fire regimes following Euro-American settlement, but information is insufficient to support any confident statements about historical disturbance regimes in these savannas. Wooded shrublands are found where local soils and climate support a shrub community, but trees can increase during moist climatic conditions and periods without disturbance and decrease during droughts and following disturbance. Dramatic increases in tree density have occurred in portions of all three types of piñon-juniper vegetation, although equally dramatic mortality events have also occurred in some areas. The potential mechanisms driving increases in tree density—such as recovery from past disturbance, natural range expansion, livestock grazing, fire exclusion, climatic variability, and $\mathrm{CO}_{2}$ fertilization-generally have not received enough empirical or experimental investigation to predict which is most important in any given location. The intent of this synthesis is 1) to provide a source of information for managers and policy makers; and 2) to stimulate researchers to address the most important unanswered questions.
\end{abstract}

\section{Resumen}

La vegetación de Piñon-junípero es un tipo de vegetación muy importante en el Oeste de Norte América. El manejo efectivo de estos ecosistemas se ha obstaculizado por el inadecuado entendimiento de 1) la variabilidad en la estructura del ecosistema y los procesos ecológicos que existen entre las diversas combinaciones de pinos, juníperos, arbustos, hierbas, y los organismos asociados del suelo; 2) regímenes prehistóricos e históricos del disturbio, y 3) mecanismos que conducen cambios en estructura y composición de la vegetación durante los últimos 150 años. Este publicación hace un resumen de lo que sabemos (y no sabemos) acerca de tres clases fundamentales de vegetación del piñon-junipero. Arbolados persistentes se

The research that forms the basis of this article has been supported by the authors' home institutions and by many other sources, including the Bureau of Land Management, the US Dept of Defense, the US Joint Fire Sciences Program, the US National Park Service, the Uncompahgre Plateau Partnership, the US Forest Service, and the US Geological Survey, among others. The workshop in which we developed the article was funded by The Nature Conservancy and the Colorado Forest Restoration Institute of Colorado State University (CSU). CSU and Université Laval (Québec, QC) provided time and resources for writing the article via a sabbatical leave for W.H.R. in 2007-2008.

Correspondence: Dr William H. Romme, Dept of Forest, Rangeland, and Watershed Stewardship, Colorado State University, Fort Collins, CO 80524, USA. Email: romme@warnercnr.colostate.edu

Manuscript received 16 September 2008; manuscript accepted 4 March 2009. 
encuentran donde los suelos locales, el clima, y los regímenes del disturbio son favorables para el piñón, el junípero, o una mezcla de ambos; los fuegos han sido siempre infrecuentes en estas áreas. Las sabanas del Piñon-junipero se encuentran donde los suelos locales y el clima son apropiados tanto para árboles y gramíneas; es lógico que los fuegos de baja-intensidad pueden haber mantenido densidades bajas de árboles antes de que se interrumpió los regímenes del fuego después del establecimiento Euro-Americano, pero existe poca información para apoyar cualquier afirmación afirmativa sobre los regímenes históricos del disturbio en estas sabanas. Los matorrales se localizan donde los suelos locales y el clima apoyan a comunidad de arbustos, pero los árboles pueden aumentar durante condiciones climáticas y períodos húmedos sin disturbio, y disminuyen durante sequías y después del disturbio. Los aumentos dramáticos en la densidad de los árboles han ocurrido en las porciones de los tres tipos de vegetación del piñon-junipero, aunque eventos igualmente dramáticos de mortalidad han ocurrido también en algunas áreas. Los mecanismos potenciales que conducen aumentos en densidad de árboles, la recuperación del último disturbio, la extensión natural del pastizal, el pastoreo del ganado, la exclusión del fuego, la variabilidad climática, y la fertilización-general del $\mathrm{CO}_{2}$ no han recibido suficiente investigación empírica o experimental para predecir cuál de estos factores puede ser el más importante en cualquiera de los sitios. El intento de esta síntesis es 1) proporcionar una fuente de información para los manejadores y los regidores, y 2) estimular a investigadores para dirigir las preguntas más importantes que aun están sin contestar.

Key Words: climate, $\mathrm{CO}_{2}$, drought, fire, grazing, tree infill, tree invasion, range expansion

\section{INTRODUCTION}

Piñon-juniper vegetation covers some 40 million ha (100 million acres) in the western United States, where it provides economic products, ecosystem services, biodiversity, and aesthetic beauty in some of the most scenic landscapes of North America. There are concerns, however, that the ecological dynamics of piñon-juniper woodlands have changed since Euro-American settlement, that stands are growing unnaturally dense, and that woodlands are encroaching into former grasslands and shrublands. Yet, despite a considerable amount of research in piñon-juniper vegetation, our understanding of historical conditions and of both historical and current ecological processes is often inadequate to answer the management questions now being posed.

Uncertainties about historical stand structures and disturbance regimes in piñon-juniper vegetation create a serious conundrum for land managers and policy makers who are charged with overseeing the semiarid landscapes of the West. Vegetation treatments are often justified, in part, by asserting that a particular treatment (e.g., tree thinning or prescribed burning) will contribute to restoration of historical conditions, i.e., those conditions that prevailed before the changes wrought by Euro-American settlers. However, in the absence of sitespecific information about historical disturbance regimes and landscape dynamics, "one-size-fits-all" treatments are likely to be ineffective, and some well-meaning "restoration" efforts may actually move piñon-juniper ecosystems further from their historical condition. Some kinds of vegetation treatments may even reorganize ecosystems in such a way that restoration of historical patterns and processes becomes more difficult.

The purpose of this article is to summarize our current understanding of historical stand structures, disturbance regimes, and landscape dynamics in piñon-juniper vegetation throughout the western United States and to highlight areas in which significant gaps in our knowledge exist. The authors gathered for a workshop in Boulder, Colorado, on 22-24 August 2006, to develop the information presented here. All the authors have conducted research in piñon-juniper vegetation and together they have experience with a wide diversity of piñon-juniper ecosystems, from New Mexico and Colorado to Nevada and Oregon.
The article is organized in three parts. In section I, we present a brief overview of the variability in dominant species, climate, stand structure, and potential fire behavior of piñon-juniper vegetation across the West to emphasize one of our key pointsthat piñon-juniper is a diverse vegetation type for which a simple model of historical structure and dynamics is inadequate. In section II, we summarize what we know about past and present conditions in three contrasting kinds of piñon-juniper ecosystems in the form of a series of concise statements followed by more detailed explanations of each statement. The explanations include the level of confidence that we have in the statement, the kinds of evidence that support the statement, and the generality of the statement, i.e., whether it applies to all piñonjuniper ecosystems or only to a subset of these ecosystems (see next paragraph). By "past conditions," we mean the three to four centuries before the sweeping changes introduced by EuroAmerican settlers in the mid- to late-1800s. In section III, we evaluate possible mechanisms driving one of the most conspicuous features of piñon-juniper vegetation in many areas-the increase in tree density that has been observed during the past 100-150 yr. We distinguish two somewhat different processes leading to higher tree density: 1) infill, or increasing tree density within existing woodlands that were previously of lower density; and 2) expansion, i.e., establishment of trees in places that were formerly nonwoodland (e.g., grassland or shrubland).

In section II, statements of high confidence generally are supported by some combination of 1) rigorous paleoecological studies that include adequate sampling and appropriate analysis of, e.g., cross-dated fire-scars, tree age structures, and macrofossils; 2) experimental tests of mechanisms that incorporate adequate replication and appropriate scope of inference; and 3) systematic observations of recent wildfires, prescribed fires, or other disturbances (e.g., insect outbreaks), either planned before the event and documented by experienced, objective observers, or based on rigorous postdisturbance analyses using adequate and spatially explicit data. Statements of moderate or low confidence generally are supported by 1) correlative studies that identify statistically significant associations between two variables but do not prove a cause-effect relationship; 2) anecdotal observations of recent fires, i.e., opportunistic observations of wildfires or prescribed fires by experienced, objective observers but that were not 
conducted in a systematic manner; and 3) logical inference, i.e., deductive inferences from related empirical or experimental studies that are logical but have not yet been tested empirically. Depending on the details, other kinds of evidence may support high, moderate, or low confidence: 1) comparison of historic and recent photographs of the same scene, which documents changes in pattern or structure, but says little about the mechanism(s) causing the changes; and 2) written historical documentation in the form of reports, articles, letters, and other accounts by reliable observers.

We intentionally refrain from making specific policy or management recommendations in this article. Instead, our objective is to provide consensus among researchers of what we know (and don't know) about the science. Although our synthesis gives much attention to historical conditions and disturbance processes in piñon-juniper vegetation, we recognize (and agree) that restoration of pre-1900 characteristics is not the only, or the most appropriate, management goal in many situations, especially in the face of climate and land-use changes (e.g., Millar et al. 2007). Nevertheless, we also believe that nearly all management goals, including those other than restoration per se, will be accomplished more successfully and economically if those goals and the techniques used to achieve them are informed by an understanding of how a particular landscape came to be the way it is today (Swetnam et al. 1999).

This article identifies major differences in historical conditions and drivers of recent changes in piñon-juniper vegetation and emphasizes that many gaps remain in our understanding of these ecosystems. We, therefore, recommend that land managers, practitioners, and policy makers rely primarily on the statements of high confidence and broad applicability in formulating management plans and priorities, and we encourage researchers to conduct new studies to critically test the statements of moderate or low confidence and to rigorously investigate the generality of these statements. In particular, we encourage collaboration between research scientists and managers in current and upcoming piñon-juniper treatments. By adding a well-designed research and monitoring component to a practical management-oriented project, not only is it possible to evaluate the efficacy of a given project but also it can improve our understanding of the more general ecological processes at work in piñon-juniper vegetation.

\section{PIÑON-JUNIPER: A DIVERSE AND VARIABLE VEGETATION TYPE}

Woodlands dominated by various combinations of piñon and juniper species represent some of the most extensive and diverse vegetation types in western North America. For example, the Southwestern Regional GAP land-cover maps (http://earth.gis. usu.edu/swgap/) show ca. $15 \%$ of the land area in New Mexico, Arizona, Colorado, Utah, and Nevada as covered by vegetation of this kind. NatureServe, an international database of species and communities (http://www.natureserve.org/ explorer/servlet/NatureServe?init $=$ Ecol) lists 77 plant associations in the West in which a piñon is the dominant species (with or without junipers) and 71 associations in which junipers dominate (typically without piñon or with piñon as a minor component). Piñon and juniper associations are found in almost every western state of the United States from California, Oregon, and Washington to North and South Dakota, Nebraska, Oklahoma, and Texas. Piñon and juniper associations also are widespread in Mexico, and juniper species extend north into Canada and east to Virginia. Although the catch-all term piñon-juniper is typically applied to all of this diverse vegetation, it is important to note that one can find pure stands of juniper (very commonly) and of piñon (less commonly) as well as mixed stands.

This article focuses primarily on piñon and juniper vegetation in the Intermountain West, the Southwest, the Southern Rocky Mountains, and the western edge of the Great Plains, including primarily the states of Oregon, Nevada, Idaho, Utah, Arizona, Wyoming, Colorado, and New Mexico. Throughout this extensive region, woodlands of piñon or juniper or a mix of both are found on almost all landforms, including ridges, hill and mountain slopes, terraces, tablelands, alluvial fans, broad basins, and valley floors. Soils are similarly variable, ranging from relatively deep soils often high in clay or sand content, to shallow rocky soils, to rock outcrops where no soil is present, but the trees are rooted in deep cracks of the bedrock. Woodlands of piñon or juniper or both occupy a broad zone of intermediate moisture and temperature conditions between the hot arid deserts of lower elevations and the cool mesic forests of higher elevations. Accordingly, soil temperature regimes range from mesic to frigid, and soil moisture regimes include aridic, xeric, and ustic (e.g., Gedney et al. 1999; Ramsey 2003; Miller et al. 2005).

There is a striking northwest-to-southeast gradient in the seasonality of precipitation (Figs. $1 \mathrm{a}$ and $1 \mathrm{~b}$ ). Winter-spring precipitation predominates in the northwest, notably in the Great Basin, shifting to a bimodal winter-summer pattern on the Colorado Plateau, and a summer monsoonal regime in the southeastern portion of the region, including southern Arizona and New Mexico (Mitchell 1976; Jacobs 2008). Total precipitation across most of the range of Juniperus occidentalis Hook. in the northwestern Great Basin varies between $25 \mathrm{~cm}$ and $40 \mathrm{~cm}$ annually, falling mostly during winter and spring storms, although this tree species can grow in areas receiving as little as $18 \mathrm{~cm}$ (usually on sandy soils) or exceeding $50 \mathrm{~cm}$ (Gedney et al. 1999). Annual precipitation amounts are similar where Juniperus monosperma (Engelm.) Sarg. grows in southcentral New Mexico, but in this latter region, $60 \%$ or more falls between April and September, particularly during the late summer "monsoon." The Colorado Plateau (especially the southern portion), lying near the midpoint of this gradient, receives small peaks of precipitation in both winter and summer (http://www. cpluhna.nau.edu/Change/modern_climatic_conditions.htm).

Species composition and vegetation structure vary along the same northwest-to-southeast gradient (Figs. 1a and 1b), and the various piñon and juniper species exhibit subtle, but ecologically significant, physiological differences both among and within species along regional and elevational gradients (Moore et al. 1999; Nowak et al. 1999). J. occidentalis is the major woodland tree species in extreme northwestern Nevada, northeastern California, and eastern Oregon; Pinus monophylla Torr. \& Frém. and Juniperus osteosperma (Torr.) Little dominate woodlands elsewhere in the Great Basin; Pinus edulis Engelm. and J. osteosperma are the dominant woodland species across most of the Colorado Plateau and southern Rocky 

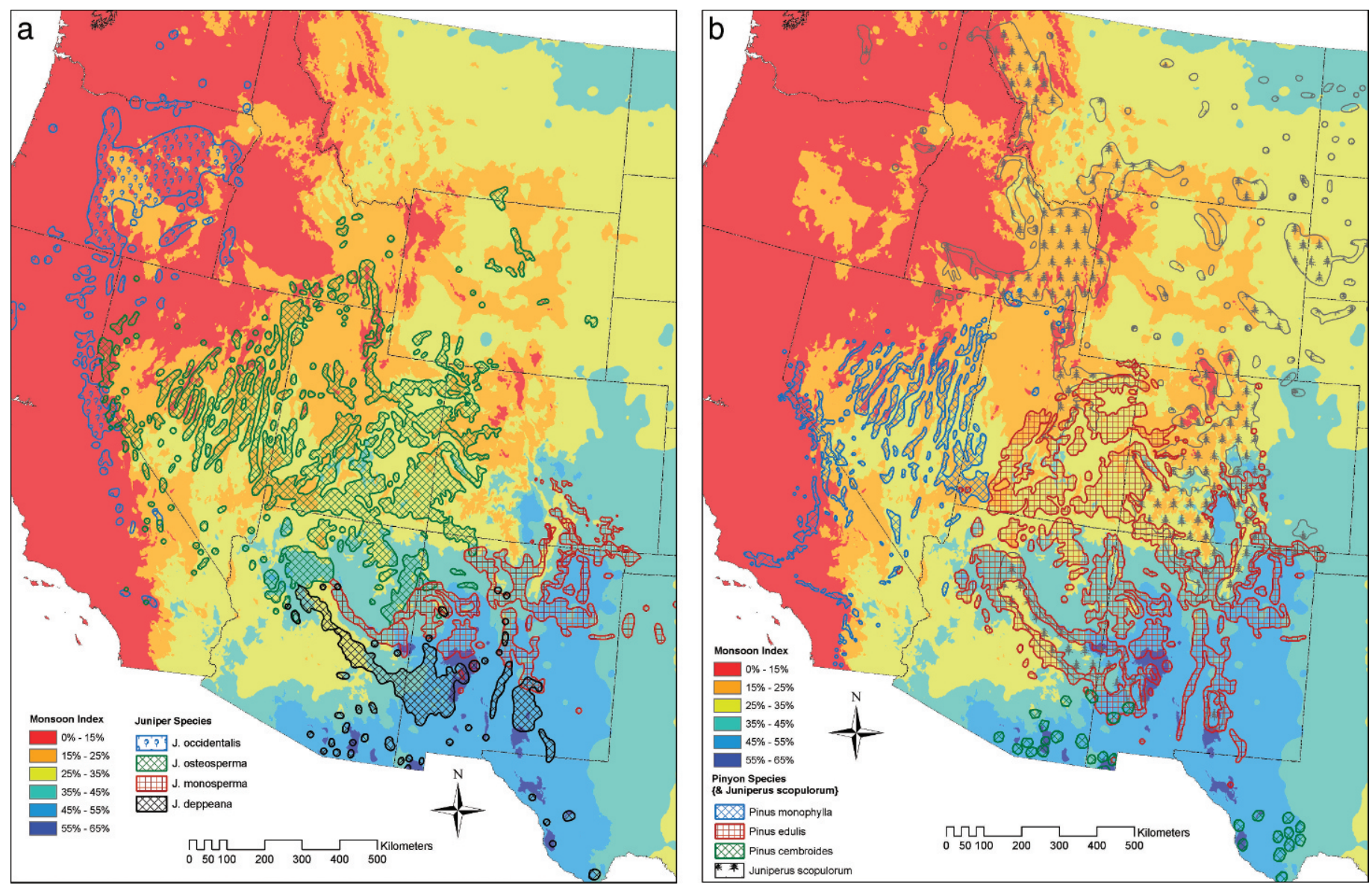

Figure 1. a, Distribution of four dominant juniper species in relation to seasonal precipitation patterns. We modified coverage based on Little (1971) using information from Southwest Regional Gap Analysis Project (SWReGAP; http://earth.gis.usu.edu/swgap/landcover.html), Springfield (1976), Jacobs (2008), and Forest Inventory Analysis data interpreted by Kristen Ironside (personal communication, 2006) to minimize overlap and clarify dominant overstory species and relationships with regional moisture patterns. Specifically, we modified the Little (1971) species distributions by 1) highlighting dominance of Juniperus monosperma in central Arizona and along the Arizona-New Mexico border, J. osteosperma in northwestern New Mexico, and $J$. deppeana in south-central Arizona; and 2) deleting J. monosperma in portions of central Colorado and southcentral New Mexico. Distribution of a fifth important, but wide-ranging, juniper species (J. scopulorum) is shown in Figure $1 \mathrm{~b}$. Distribution of Juniperus coahuilensis (Martiñez) Gaussen ex R. P. Adams (sensu Juniperus erythrocarpa Cory var. coahuilensis Martinez) is not shown but is largely coincident with $J$. deppeana in southeastern Arizona. Juniper species with ranges largely to the east, such as Juniperus pinchotii Sudw., Juniperus ashei J. Buchholz, and Juniperus virginiana L., are also not shown. Monsoon Index represents July to September precipitation as a percentage of annual total (calculated from 800-m PRISM data) and highlights a pronounced northwest to southeast moisture seasonality gradient from winter to summer moisture dominance. b. Distribution of three dominant piñon species (and J. scopulorum) in relation to seasonal precipitation patterns. Scattered areas of J. scopulorum that overlap with Pinus edulis and P. monophylla in eastern Nevada, south-central Utah, northern Arizona, and central New Mexico are not shown to improve clarity. Distribution of Pinus quadrifolia Parl. ex Sudw. is not shown. Monsoon Index represents July to September precipitation as a percentage of annual total (calculated from 800-m PRISM data) and highlights a pronounced northwest to southeast moisture seasonality gradient from winter to summer moisture dominance.

Mountains west of the Continental Divide; and P. edulis and $J$. monosperma characterize the summer monsoon regions of New Mexico, east-central Arizona, and the southern Rockies, east of the Continental Divide. Juniperus scopulorum Sarg. is common at higher elevations on much of the Colorado Plateau and in the southern Rockies, and Juniperus deppeana Steud. becomes dominant in areas of southern New Mexico and Arizona where warmer temperatures and stronger monsoonal patterns prevail. In the western and northern regions, where precipitation is winter-dominated, the trees are typically associated with a major shrub component, notably big sagebrush (Artemisia tridentata Nutt.) and other Artemisia L. spp., Purshia tridentata (Pursh) DC., Chrysothamnus Nutt. spp., Ericameria Nutt. spp., and Cercocarpus Kunth spp. Perennial tussock grasses may also be common associates, e.g., Festuca idahoensis Elmer, Pseudoroegneria spicata (Pursh) A. Löve, Achnatherum P. Beauv. spp., Poa secunda J. Presl, and Poa fendleriana (Steud.) Vasey. In eastern and southern regions, where the precipitation pattern is summer-dominated, piñon and juniper woodlands often support an understory of warm-season grasses, e.g., Bouteloua gracilis (Willd. ex Kunth) Lag. ex Griffiths, Bouteloua curtipendula (Michx.) Torr., Bouteloua hirsuta Lag., Boutelona eriopoda (Torr.) Torr., Mublenbergia pauciflora Buckley, and Mublenbergia setifolia Vasey, and woodlands may occur as patches within a grassland matrix. A diverse and highly variable mix of montane shrubs 
and chaparral species (e.g., Quercus gambelii Nutt., Quercus pauciloba Rydb. [Pro sp.], and other Quercus L. spp.; Cercocarpus montanus Raf.; Amelanchier utahensis Koehne; and $P$. tridentata) is an important component of piñon-juniper vegetation at higher elevations, notably in the southern Rockies and Colorado Plateau.

\section{Three General Kinds of Piñon-Juniper Vegetation}

We identify three fundamentally different kinds of piñonjuniper vegetation, based primarily on canopy structure, understory characteristics, and historical disturbance regimes. The three kinds-persistent piñon-juniper woodlands, piñonjuniper savannas, and wooded shrublands-are summarized in Table 1, and their general structure and distribution in relation to precipitation gradients is depicted in Figure 2. There is great diversity within each of these general types with respect to species composition and stand structure, but this classification represents much of the variability in piñon-juniper vegetation across the western United States. Research is underway to link these vegetation types to specific environmental characteristics that would allow for reliable prediction and mapping across large landscapes and regions, but at present, we can identify only some very general environmental correlates. Because historical stand structures, disturbance regimes, and landscape dynamics were significantly different among these three basic types of piñon-juniper vegetation, we are careful to distinguish among the types in sections II and III below.

\section{Potential Fire Behavior}

In all three kinds of piñon-juniper vegetation (Table 1), there are important interactions among canopy fuel structure, understory fuel structure, and fire weather conditions (Fig. 3). Continuity of canopy aerial fuels (the horizontal axis in Fig. 3) is key in determining crown fire behavior, especially in woodlands where understory shrubs are relatively sparse. Canopy fuel continuity is influenced most directly by total tree stem density, crown width, and crown fullness and continuity between individuals (often related to tree age and total stand age). Understory vegetation is relatively lacking in very dense woodlands, creating empty cells in Figure 3; however, in other woodlands, the understory may provide continuity among tree stems and ladder fuels under trees, especially where tall shrubs are present. Where Artemisia tridentata or a similar large shrub is a dominant shrub species, the shrub stratum is likely more important than the trees in carrying fire, especially if the trees are widely spaced. Also fundamental to fire behavior is total surface-fuel loading (the vertical axis in Fig. 3), influenced most directly by total biomass of small trees that provide litter fall, but most importantly by shrubs and other understory vegetation as well. Piñon and juniper are able to become established and persist in very dry sites with widely spaced trees and a range of understory conditions. These often-complex arrangements of overstory and understory factors form a matrix of likely fire behavior, which would vary between modal (e.g., 80th percentile) and extreme (e.g., 95th percentile) fire weather conditions across all three piñon-juniper types (Fig. 3). This, in turn, affects residual structure, composition, and function over time.

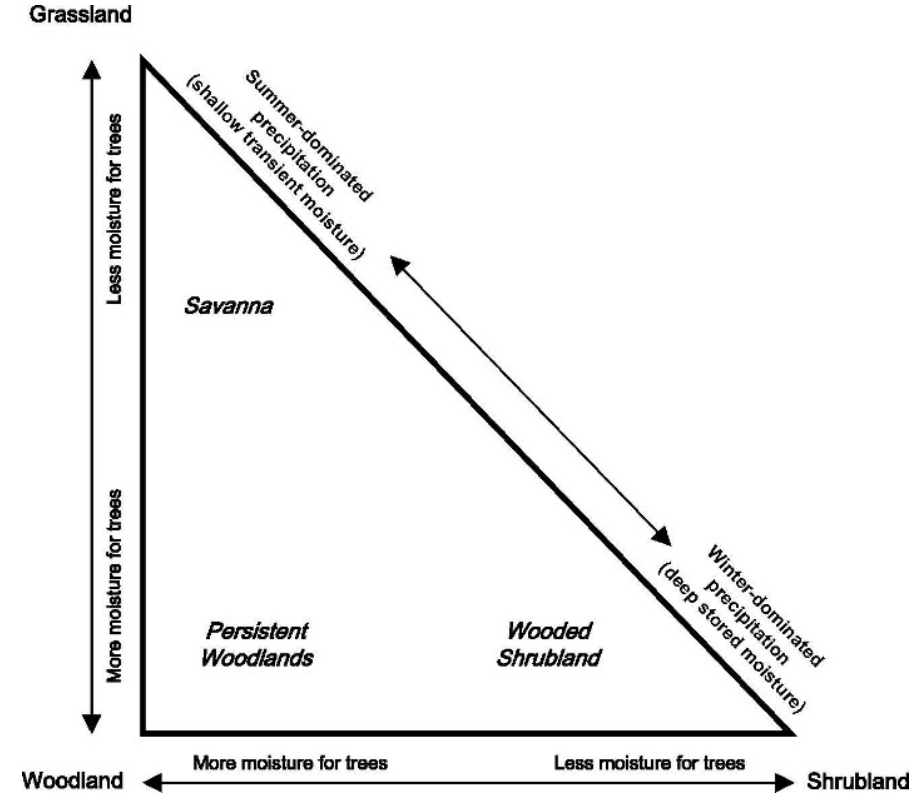

Figure 2. A general framework for the distribution of three broad types of western piñon and juniper woodlands (persistent woodland, savanna, and wooded shrubland; Table 1). These types are commonly situated in relation to the gradients of soil moisture that is available for trees and the regional seasonality of precipitation. However, at any local site, conditions such as substrate, landscape position, and disturbance regimes may support any of the three types, even where one type is generally more prevalent at the regional scale.

Actual fire weather is critical in most combinations of tree, shrub, and understory cover types (Fig. 3); weather conditions determine the amount of tree mortality and the dynamics of fire spread, both within a stand and across a landscape in all three types of piñon-juniper vegetation. However, stands with scattered trees among sparse understories of low shrubs and herbs almost always exhibit limited fire activity, given the general lack of fuel, and the trees growing in such a stand are relatively protected from fire. Conversely, dense woodland conditions become highly flammable with time (i.e., fuel accumulation over decades or centuries) regardless of fine fuel conditions; the probability of ignition and duration of the fire season define the actual fire return intervals for these ecosystems in which fire is typically stand-replacing. It is also important to distinguish between passive crown fires (torching of individual trees) versus active crown fires (running through the crowns of most trees); the probability of passive or active crown fire is related to overstory and understory fuel arrangements as well as extreme versus modal fire weather in all three piñon-juniper types (Fig. 3). If overstory and understory densities are relatively low, as in many very dry or rocky sites, even under the most extreme weather conditions there simply may not be enough fuel for either active or passive crown fires to occur; the fire may simply go out before traveling through a stand.

\section{WHAT WE KNOW ABOUT PIÑON- JUNIPER ECOSYSTEMS}

\section{Statement 1: Spreading, Low-Intensity, Surface Fires}

Spreading, low-intensity, surface fires had a very limited role in molding stand structure and dynamics of many or most piñon 
Table 1. Three general types of piñon and juniper vegetation. A field key to the three types is provided in Romme et al. (2007). Broad-scale structural and climatic patterns are depicted in Figure 2.

\begin{tabular}{|c|c|}
\hline Vegetation type and characteristics & Description \\
\hline \multicolumn{2}{|l|}{ Persistent piñon-juniper woodlands } \\
\hline Canopy & $\begin{array}{l}\text { Ranging from sparse stands of scattered, small trees growing on poor substrates to relatively dense stands of } \\
\text { large trees on more productive sites. The canopy may be dominated by either piñon or juniper or both and } \\
\text { may include any of the species depicted in Figures } 1 \mathrm{a} \text { and } 1 \mathrm{~b} \text {. }\end{array}$ \\
\hline Understory & $\begin{array}{l}\text { Variable cover of shrubs, subshrubs, forbs, and grasses, but often sparse, with extensive areas of litter } \\
\text { (beneath canopies) and bare soil or rock (intercanopy). }\end{array}$ \\
\hline Site conditions & $\begin{array}{l}\text { Associated with a wide variety of substrates and topographic settings but most commonly found on rugged } \\
\text { uplands with shallow, coarse-textured, and often rocky soils that support relatively sparse herbaceous cover; } \\
\text { site conditions (soils and climate) and disturbance regimes (notably infrequent fire) are inherently favorable } \\
\text { for tree growth. }\end{array}$ \\
\hline Regional distribution & $\begin{array}{l}\text { Found in appropriate upland locations throughout the West. Persistent woodlands appear to be especially } \\
\text { prevalent on portions of the Colorado Plateau, where precipitation is bimodal, with small peaks in winter and } \\
\text { summer. }\end{array}$ \\
\hline \multicolumn{2}{|l|}{ Piñon-juniper savannas } \\
\hline Canopy & $\begin{array}{l}\text { Low to moderate density and cover of piñon or juniper or both; the most common dominants are } P \text {. edulis, J. } \\
\text { monosperma, and J. deppeana. }\end{array}$ \\
\hline Understory & $\begin{array}{l}\text { Well-developed and nearly continuous grass (with forb) cover; shrubs may be present but are usually only a } \\
\text { minor component. }\end{array}$ \\
\hline Site conditions & $\begin{array}{l}\text { Typically found on moderately deep, coarse to fine-textured soils in gentle upland and transitional valley } \\
\text { settings or where local conditions are inherently favorable for grasses. }\end{array}$ \\
\hline Regional distribution & $\begin{array}{l}\text { Especially prevalent in basins and foothills of New Mexico and Arizona, where a large proportion of annual } \\
\text { precipitation comes during the growing season. }\end{array}$ \\
\hline \multicolumn{2}{|l|}{ Wooded shrublands } \\
\hline Canopy & $\begin{array}{l}\text { Variable tree component that may range from very sparse to relatively dense and may include any of the piñon } \\
\text { and juniper species depicted in Figures } 1 \mathrm{a} \text { and } 1 \mathrm{~b} \text {; however, J. monosperma and } \mathrm{J} \text {. deppeana are more } \\
\text { commonly associated with persistent woodlands and savannas. }\end{array}$ \\
\hline Understory & $\begin{array}{l}\text { Well-developed shrub stratum with variable grass-forb cover and composition; shrubs constitute the } \\
\text { underlying biotic community in these ecosystems. }\end{array}$ \\
\hline Site conditions & $\begin{array}{l}\text { Associated with a wide variety of substrates and topographic settings, including shallow, rocky soils on } \\
\text { mountain slopes to deep soils of intermontane valleys; site conditions are inherently favorable for shrub } \\
\text { growth; thus, the tree component naturally waxes and wanes over time in response to a variety of climatic } \\
\text { and disturbance factors ("areas of potential expansion and contraction" in Romme et al. 2007). }\end{array}$ \\
\hline Regional distribution & $\begin{array}{l}\text { Especially prevalent in the Great Basin, where the precipitation pattern is winter dominated and } A \text {. tridentata is } \\
\text { a dominant shrub species; however, wooded shrublands can be found throughout the West, where local } \\
\text { substrates favor shrub dominance. }\end{array}$ \\
\hline
\end{tabular}

and juniper woodlands in the historical landscape. Historical fires generally did not thin from below, i.e., they did not kill predominantly small trees. Instead, the dominant fire effect was to kill most or all trees and to top-kill most or all shrubs within the burned area, regardless of tree or shrub size. This statement is also true of most ecologically significant fires today.

Applicability and Confidence. This statement is well supported by empirical research in persistent woodlands and wooded shrublands, and we state it with high confidence for these types (persistent woodlands and wooded shrublands). Pre-1900 disturbance regimes in piñon-juniper savannas are not well understood; consequently, we have only low or moderate confidence that this applies to savannas.

Explanation. Spreading, low-intensity, surface fires (as opposed to stand-replacing fires) have been observed only rarely in piñon-juniper vegetation during the recent period since Euro-American settlement (Baker and Shinneman 2004). Apparently, such fire behavior was also rare in persistent woodlands and wooded shrublands before Euro-American settlement. Definitive fire-history evidence of a spreading, low-intensity, surface fire would include cross-dated fire scars at two or more locations along with intervening age-structure evidence that trees generally survived the fire (Baker and Shinneman 2004). However, few places provide such evidence. On the contrary, fire scars are conspicuously absent or rare in most piñon-juniper stands (Baker and Shinneman 2004; but see Burkhardt and Tisdale 1976; Wilkinson 1997; Brown et al. 2001; and Camp et al. 2006 for examples of studies where some fire scars were found).

Even when one finds fire-scarred trees, that evidence, by itself, does not necessarily confirm a history of low-severity, 


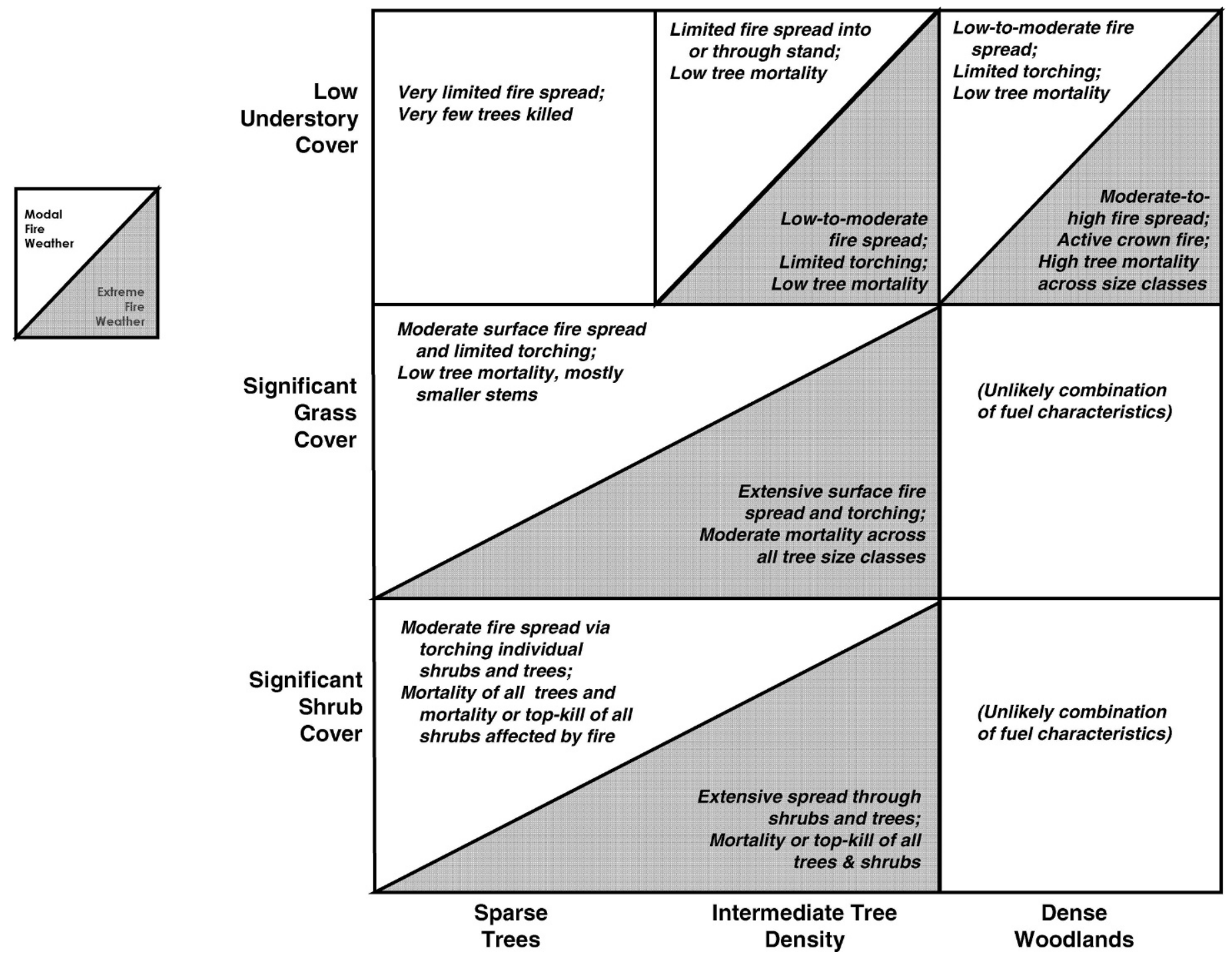

Figure 3. Probable fire behavior following a single ignition event in piñon and juniper vegetation with respect to variability in tree density (horizontal axis) and understory fuel characteristics (vertical axis). Split cells reflect variable fire behavior, spread dynamics, and tree mortality under modal (80th percentile fire weather) in the unshaded upper left vs. extreme (95th percentile) fire weather conditions in the shaded lower right.

spreading fire in piñon-juniper woodlands. For example, at the upper ecotone between piñon-juniper and ponderosa pine (Pinus ponderosa Douglas ex Lawson \& C. Lawson) forest, at a site in northern New Mexico, two studies dated fire scars on ponderosa pine trees and documented 10-13 spreading fires during ca. 250 yr (Allen 1989, Morino et al. 1998). Evidence on tree survival among the fire-scarred trees was not collected, however, so it is not clear whether the fire actually burned the entire area or spread primarily through ponderosa pine stringers and around the islands of piñon-juniper that may have lacked sufficient fine fuels to support low-intensity, surface fires. Fire scars were also found on piñon trees at the ecotone between an open ponderosa pine forest and a piñonjuniper woodland in south-central New Mexico (Muldavin et al. 2003); again, however, tree-age data were not sufficient to confidently reconstruct the spatial patterns of fire spread within the piñon-juniper woodland. Huffman et al. (2008) recently sampled fire scars and ages of all tree species throughout two study sites located at ecotones between piñon-juniper and ponderosa pine forests in northern Arizona and New Mexico; they concluded that the historical fires documented in the ponderosa pine forests generally did not spread through the adjacent piñon-juniper portions of the study areas.

A major reason why low-severity fires apparently are unimportant in most piñon and juniper vegetation is that the fuel structure, especially in persistent woodlands and in wooded shrublands, is not typically conducive to a spreading, low-severity fire that would spread via fine fuels without killing the dominant trees or shrubs. Fine fuels are usually discontinuous (Floyd et al. 2000, Baker and Shinneman 2004), and the major fuel components are the crowns of live shrubs and trees, which, if ignited, tend to burn completely with considerable heat release (Baker 2006; R. Tausch, personal observations). Thus, fires typically kill all of the trees and top-kill all the shrubs and herbs within the areas that burn; usually, the only surviving plants are those in patches that do not burn. 
Logically, it would seem that the fuel structure of piñon and juniper savannas could support spreading, low-severity fire because of the grass component and that the climate in regions having extensive savanna could be conducive to widespread fire during dry seasons. This idea is depicted in Figure 3 as a possible exception to our statement that low-severity fires are generally unimportant in piñon and juniper vegetation. However, rigorous empirical information on historical disturbance regimes in these ecosystems is lacking. Consequently, we were unable to develop any confident statements about the frequency or importance of fire, insect, disease, or climatic variability in the dynamics of piñon and juniper savannas in the historical landscape. As emphasized in the section on research priorities in Romme et al. (2008), obtaining this information should be a high priority for researchers.

A major problem in assessing the historical role (or lack of a role) of low-severity, surface fires in piñon and juniper woodlands is that we do not know how often the trees scar when surface fires burn in their vicinity (Romme et al. 2008). Nevertheless, available evidence indicates that low-severity fires were generally absent in most piñon and juniper woodlands, and if they did occur, they were likely patchy and of small extent (Baker and Shinneman 2004).

In contrast to the lack of evidence for spreading, low-severity fires, there is abundant evidence that fires in piñon and juniper woodlands, since Euro-American settlement, have been predominantly high-severity fires, commonly killing all the trees and top-killing the shrubs and herbs within the fire perimeter but often leaving some unburned islands of woodland (Baker and Shinneman 2004). Fire-history studies and historical evidence also document high-severity fires in multiple locations around the West during the pre-Euro-American era (Eisenhart 2004; Floyd et al. 2004, 2008; Bauer 2006; Shinneman and Baker 2009). Limited evidence suggests that fires could, occasionally, have been variable in severity, resulting in some low-severity areas on the margins of large, high-severity fires, or in small islands not burned at high severity (Baker and Shinneman 2004). Nevertheless, high-severity fire was likely the dominant type of fire in these woodlands in both historical and modern eras.

Two major reasons why fires tend to burn with high severity in piñon and juniper vegetation are 1) the usual fuel structure, as explained above; and 2) that almost all piñons and junipers are relatively intolerant to fire because of their thin barks and typically low crowns. Unlike ponderosa pine, which self-prunes lower branches and develops thick bark with age, piñons and most juniper species are usually killed by fire, even when mature. We note, however, that older piñons can have bark $>2$ $\mathrm{cm}$ thick, and it is unknown how these trees may have responded to historical, surface fires, if they occurred. Mature J. deppeana trees can also survive fire, and they commonly resprout if top-killed by fire.

The extent and spatial pattern of high-severity fire varies in time and space from very small $(<0.1 \mathrm{ha})$ and fine grained to very large and coarse grained (hundreds to thousands of hectares) as a function of fuel structure and fire weather (Fig. 3). Although we know that high-severity fires occurred in the past, we have little specific data on fire sizes and spatial patterns during the pre-Euro-American period (but see Floyd et al. 2004, 2008; Huffman et al. 2008). Nevertheless, the dominant effect observed in recent fires in piñon-juniper vegetation has been complete or nearly complete tree mortality throughout the area burned, and the effect was likely similar in historical fires.

\section{Statement 2: Disturbances Other Than Fire}

In many piñon and juniper woodlands, stand dynamics are driven more by climatic fluctuation, insects, and disease than by fire. Although increases in piñon and juniper density have received much attention in many areas (see statement 5 below), loss of piñon and juniper (especially from marginal sites) has also occurred recently and in the past. For example, a widespread and severe piñon mortality event occurred in 2002-2004 in the Four Corners region (Colorado, Arizona, New Mexico, and Utah) as a result of drought, high temperatures, and bark beetle outbreaks.

Applicability and Confidence. This statement is well supported by empirical research in persistent woodlands, and we state it with high confidence for this type (persistent woodlands). The historical role of climatic fluctuation, insects, and disease is less well known for wooded shrublands and is almost unknown for savannas; consequently, we make this statement with moderate and low confidence, respectively, for these two types (wooded shrublands and savannas).

Explanation. Scientists and managers have traditionally placed greater emphasis on wildfire as a shaper of piñon and juniper ecosystems than on other types of natural disturbance. Increasingly, however, there is awareness that the dynamics in many piñon and juniper woodlands are driven more by drought stress and its accompanying suite of diseases, insects, and parasites than by fire. Indeed, studies of old piñon and juniper woodlands often reveal an accumulation of coarse wood in the understory from trees that were killed by agents other than fire and have persisted because of the absence of fire (Betancourt et al. 1993; Waichler et al. 2001; Floyd et al. 2003; Eisenhart 2004).

Chronic, low-level tree mortality results from local insect and disease processes, e.g., native black stain root disease (Leptographium wageneri [W.B. Kendr.] M.J. Wingf.) on P. edulis in southwestern Colorado (Kearns and Jacobi 2005). Stand dynamics are also punctuated more dramatically by episodic mortality or by recruitment events that occur in response to extreme weather patterns and insect outbreaks (Betancourt et al. 1993; Swetnam and Betancourt 1998; Knapp and Soulé 1999; Soulé and Knapp 2007). For example, substantial $P$. edulis mortality occurred in many parts of New Mexico during the severe, regional drought of the 1950s (Swetnam et al. 1999). More recently, drought and high temperatures in 2002-2004 caused high mortality of $P$. edulis throughout the Four Corners region (Breshears et al. 2005; Shaw et al. 2005; Greenwood and Weisberg 2008) and shifted canopy dominance of some stands from piñon to juniper (Mueller et al. 2005). Mortality data from this recent drought event indicate that trees of cone-bearing age were more likely to die (Mueller et al. 2005; Selby 2005; C. D. Allen, unpublished data, 2008; M. L. Floyd, unpublished data, 2008), which will likely influence the trajectory of recovery for decades. (We note, however, that abundant 
piñon reproduction is now present in at least some affected stands; B. Jacobs, unpublished data, 2008).

Climatic reconstructions based on tree rings from throughout the West demonstrate that the recent Four Corners drought is not unprecedented and that droughts of similar or greater magnitude have occurred many times in the past (Betancourt et al. 1993; Ni et al. 2002; Gray et al. 2003). For example, widespread tree mortality during a very severe megadrought in the late 1500s may explain the rarity of piñon older than $400 \mathrm{yr}$ in the Southwest (Swetnam and Brown 1992; Betancourt et al. 1993; Swetnam and Betancourt 1998). Studies in the Southwest also demonstrate that recovery from drought may occur as a pulse of tree establishment and recruitment during the first wet period that follows the drought (Swetnam et al. 1999; Gray et al. 2006; Shinneman and Baker 2009). In some areas, in fact, recovery since the late 1500 s megadrought may be responsible for recent and ongoing increases in tree density (see section III below).

Although recent woodland expansion has received much attention (see statement 5), contraction of woodlands has also been documented. For example, some of the 20th century expansion of woodland trees into sagebrush on the Uncompahgre Plateau in western Colorado appears now to be undergoing reversal as young trees have died in recent droughts (K. Eisenhart, unpublished data, 2008). Thus, for thousands of years, tree expansion and contraction may have been a normal part of climatically driven fluctuations in woodland densities, perhaps especially at the ecotones with sagebrush, grasslands, and other nonwoodland vegetation. Savannas and wooded shrublands, in particular, are probably dominated by trees during periods of moist climatic conditions or infrequent fires, but by grasses or shrubs during droughts or periods with more frequent fires or insect outbreaks. It follows that the recently observed woodland infill and expansion may be reversed by future contractions of woodland in at least some areas.

\section{Statement 3: Fire Intervals and Rotations}

Historical fire rotations (i.e., the time required for the cumulative area burned to equal the size of the entire area of interest) and fire intervals, at the stand level, varied from place to place in piñon and juniper woodlands but, in many places, were very long (generally measured in centuries). Indeed, some piñon and juniper woodlands have been stable for hundreds of years without fire, other than isolated lightning ignitions that burned only single trees or small patches and produced no significant changes in stand structure. Many piñon and juniper woodlands today show no evidence of past widespread fire, although they may have burned extensively in the very remote past (many hundreds or thousands of years ago).

Applicability and Confidence. This statement is well supported by empirical research in persistent woodlands, and we state it with high confidence for this type (persistent woodlands). We have little quantitative information on fire history in wooded shrublands and consequently we have only moderate confidence in this statement for this type (wooded shrublands). Fire intervals may have been substantially shorter in piñon-juniper savannas than in the other two types (persistent woodlands and wooded shrublands), but we have almost no empirical data on pre-1900 fire regimes in savannas and therefore we have low confidence in our statements about this type (savannas).

Explanation. Only a few rigorous estimates of historical fire rotation for piñon-juniper woodlands have been made on the basis of adequate empirical data, but these studies all report very long rotations. Examples include $410 \mathrm{yr}$ or $427 \mathrm{yr}$ (depending on the method of calculation) in Barrett Canyon of central Nevada (Bauer 2006), 480 yr in southern California (Wangler and Minnich 1996), 400-600+ yr on the Uncompahgre Plateau in western Colorado (Shinneman and Baker 2009), and 400+ yr on Mesa Verde in southwestern Colorado and on the Kaiparowits Plateau of southern Utah (Floyd et al. 2004, 2008). Huffman et al. (2008) estimated shorter rotations of 340 yr and $290 \mathrm{yr}$ at two sites in northern Arizona and New Mexico, respectively, but these sites represented ecotones between piñon-juniper woodlands and ponderosa pine forests. Note that fire rotation is a different concept and metric than mean composite fire interval. Because the latter metric may be influenced strongly by sampling intensity and scale (Hardy 2005; Reed 2006), we emphasize here the fire rotation concept, which is roughly equivalent to the average fire interval at a small point on the ground. We emphasize that that historical fire rotations and point intervals were much longer than is often assumed for piñon or juniper vegetation in general (e.g., Schmidt et al. 2002). We also note that modern fire intervals may be getting shorter, as explained in statement 4 below.

Consistent with the idea of very long fire rotations, many persistent woodlands exhibit little to no evidence that they ever sustained widespread fires during the period that the trees in the stand have been alive. Living trees in these stands are typically very old (300-1000 yr) and exhibit multiaged structure, often reflecting episodic tree recruitment events (see, e.g., Waichler et al. 2001; Floyd et al. 2003, 2004, 2008; Eisenhart 2004; Shinneman and Baker 2009). It is difficult to accurately gauge the time since the last major disturbance from living trees alone in such stands because they typically contain even older logs or snags that overlap the time spans of the living trees (i.e., they were not killed in a past stand-opening event). Charred snags and logs are either absent or extremely sparse. There may be individual charred boles or small patches of charred boles, which apparently represent lightning ignitions in the past that failed to spread, but no extensive or continuous evidence of past fire.

Ancient, persistent woodlands are often located on rocky or unproductive sites with widely scattered trees, where understories are mainly bare ground with sparse vegetative cover. However, they also include some higher-density woodlands growing on more productive sites (see, e.g., Floyd et al. 2004, 2008), and they may cover extremely large portions of some areas, such as the mesas, plateaus, and bajadas in southern Utah, western Colorado, northern Arizona, and northwestern New Mexico. Examples of locations where tree-ring data document old trees and a lack of widespread fire include pumice-sandy soils in central Oregon (Waichler et al. 2001); near the northeastern edge of the Uinta Range in Utah (Gray et al. 2006); the Tavaputs Plateau and several of the bajada communities on the fringes of the southern Utah mountain ranges (E. K. Heyerdahl, P. M. Brown, and S. T. Kitchen, unpublished data, 2009); the Kaiparowits Plateau in Utah 
(Floyd et al. 2008); Mesa Verde, the Uncompahgre Plateau, and Black Canyon of the Gunnison in western Colorado (Eisenhart 2004; Floyd et al. 2004; Shinneman and Baker 2009); and the margins of the Chihuahuan Desert in central and southern New Mexico (Swetnam and Betancourt 1998; Muldavin et al. 2003; E. Muldavin, C. Baisan, T. W. Swetnam, L. DeLay, and K. Morino, unpublished data, 2008; T. W. Swetnam and J. L. Betancourt, unpublished data, 2008). Persistent woodlands of this kind are especially prevalent in portions of the Colorado Plateau and Great Basin. They also probably occur throughout the range of piñon and juniper vegetation, although they may be less common in regions having monsoon-dominated precipitation patterns, such as southern New Mexico (Fuchs 2002; E. C. Fuchs, personal communication, March 2007).

\section{Statement 4: Recent and Historic Stand-Replacing Fires}

Recent, large, severe (stand-replacing) fires in piñon and juniper woodlands are, for the most part, similar to fires that occurred historically.

Applicability and Confidence. This statement is best supported by empirical research in persistent woodlands, where some large, severe, pre-1900 fires have been documented. However, it is unclear whether the very large size of some recent, standreplacing fires is exceptional (because of changing climate or fuels conditions) or represents a kind of infrequent, but nevertheless natural, event in this vegetation type (persistent woodlands). Consequently, we make this statement with moderate confidence for persistent woodlands. Historical fire size and severity are less well documented for wooded shrublands and very poorly documented for savannas; consequently, we make this statement with low confidence for these two types (wooded shrublands and savannas).

Explanation. An upsurge of large fires ( $>400$ ha) in forested landscapes throughout much of the western United States began in the mid-1980s (Westerling et al. 2006). Increasing trends in large fire frequency and total area burned are particularly noticeable in some regions having extensive piñon-juniper woodlands (e.g., the Southwest and the northern Great Basin). For example, a greater proportion of the piñonjuniper woodland on Mesa Verde, Colorado, burned in the decade between 1995 and 2005 than had burned throughout the previous $200 \mathrm{yr}$ (Floyd et al. 2004).

We know that large, severe fires occurred in piñon-juniper woodlands in the past, although we have little information on extents or spatial patterns of those fires. Truncated age structures of live piñon trees and abundant, charred juniper snags document the occurrence of large fires (at least hundreds of hectares in extent) in the 1700s on Mesa Verde in western Colorado and in the 1700 s or 1800 s on the Kaiparowits Plateau of southern Utah (Floyd et al. 2004, 2008). In southcentral New Mexico, an extensive shrubland patch embedded within otherwise continuous piñon-juniper woodlands of the Oscura Mountains is suggestive of a high-severity fire in the 1800 s, although the tree-ring studies needed to confirm this hypothesis have not yet been conducted (Muldavin et al. 2003). Thus, it follows that the recent occurrence of high-severity fires in piñon and juniper woodlands is not unprecedented; however, we have inadequate historical information with which to confidently evaluate how the frequency and extent of recent high-severity fires in this vegetation type compare with historical fire events.

Changes in fuel structure have probably contributed to the recent increase in large fires in some parts of the West. For example, fire exclusion in some ponderosa pine and dry, mixed-conifer forests has allowed fuel mass and vertical continuity to increase (Allen et al. 2002; Hessburg and Agee 2003), although recovery from 19th-century fires, logging, and livestock grazing, rather than fire exclusion, are likely the principal mechanisms of this change in other ponderosa pine forests (Baker et al. 2007). Invasion by highly flammable annual grasses (e.g., cheatgrass, Bromus tectorum L.) has increased horizontal fuel continuity and likelihood of extensive fire spread in many semiarid vegetation types, including piñonjuniper woodlands and shrublands of the Great Basin and Colorado Plateau (Whisenant 1990; Knapp 1996).

However, frequency of large fires also has increased in other forest types, where changes in fuel conditions are probably far less important, e.g., in high-elevation forests of the northern Rocky Mountains (Schoennagel et al. 2004), leading Westerling et al. (2006) to suggest that an equal or more important mechanism may involve the warmer temperatures, longer fire seasons, and high amplitude of wet/dry years in recent decades. A trend of lower frequency and later onset of midlatitude summer cyclones (which bring cool or moist conditions to interior North America) may also contribute to the recent upsurge in large fires (Knapp and Soulé 2007). A similar increase in the frequency of large fires has also been documented in portions of Canada, where changes in forest conditions due to land use are minimal, again suggesting a primarily climatic mechanism (Gillet et al. 2004; Girardin 2007). It should be noted that although increases in numbers of large fires and area burned are striking in some regions and in broad composite data from the western United States and Canada, some subregions show little or no clear evidence of major changes in fire activity in recent decades (Westerling et al. 2006).

Given the very long fire rotations that naturally characterize piñon and juniper woodlands, especially persistent woodlands (see statement 3), we cannot yet determine whether the recent increase in frequency of large fires occurring in this vegetation type represents genuine directional change related to changing climate or fuel conditions or is simply a temporary episode of increased fire activity, comparable to similar episodes in the past. In any event, the suite of current and upcoming broadscale environmental changes-warming temperatures, increasing tree densities in some areas (see statement 5), and expansion of fire-promoting species, such as cheatgrass-may all interact to dramatically increase the amount of burning in piñonjuniper and other vegetation types over the next century.

\section{Statement 5: Tree Density and Canopy Cover}

Tree density and canopy coverage have increased substantially during the past 150 yr in many piñon and juniper woodlands but have not changed or have declined in others. Former grasslands and shrublands in some regions have also been converted to savanna or woodland as trees have expanded into 
previously nonwoodland sites, but expansion has been less common or nearly lacking in other regions.

Applicability and Confidence. This statement is well supported by photographic evidence and age-structure data from many different locations across the West, where an increase or a decrease or no change is apparent in persistent woodlands, wooded shrublands, and savannas. Consequently, we state it with high confidence for all three types of piñon and juniper vegetation.

Explanation. Infill of previously existing piñon and juniper woodlands and expansion of piñon and juniper into former grasslands and shrublands during the past $150 \mathrm{yr}$ have been well documented in many parts of the western United States (examples below). However, the pattern of infill and expansion is not uniform throughout the region. For example, a comparison of aerial photographs from 1937, 1965-1967, and 1994 on the Uncompahgre Plateau in western Colorado revealed minimal net change in density or extent of piñonjuniper woodlands (Manier et al. 2005). Sallach (1986) documented increasing tree densities in many locations in New Mexico but also declines in the abundance of piñon and juniper in other places; similarly, B. Bestelmeyer (unpublished data, 2008) recorded both local density increases and decreases (from tree harvest) since the 1930s in a central New Mexico study area. Therefore, one cannot necessarily assume that piñon and juniper are increasing in density in any particular portion of their range without local data.

Infill and expansion have occurred over extensive portions of the Great Basin. For example, tree age structures in old persistent woodlands of central Nevada show dramatic increases in establishment of new trees beginning in ca. 1880 (Bauer 2006). On tablelands of southeast Oregon and southwest Idaho, where low sagebrush (Artemisia arbuscula Nutt.) is the predominant woody layer, but scattered $J$. occidentalis trees are also present, sampling of live and dead trees revealed a gradual increase in tree densities since the late 1800s in many areas (Johnson and Miller 2006). In some places, however, the magnitude of infill has been relatively small. For example, in central Oregon, just east of the Cascade Mountains, $>67 \%$ of the trees $>1 \mathrm{~m}$ in height became established before 1870 , and most individuals $<1 \mathrm{~m}$ in height were growing slowly with very narrow rings-demonstrating that small trees actually may be relatively old, especially on sites with poor growing conditions (Waichler et al. 2001). In a dense, old, persistent woodland occupying $>1000$ ha in southeast Oregon, infill is occurring in the outer edges of the stand, but little infill has occurred in much of the main core where understory trees of $0.5 \mathrm{~m}$ and $1.0 \mathrm{~m}$ in height are 100 $250 \mathrm{yr}$ old (R. F. Miller, unpublished data, 2008).

Impressive infill and expansion of trees has also occurred in wooded shrublands and sagebrush-grasslands of the Great Basin, where woodland area may have increased by an order of magnitude since the mid-19th century (Miller and Tausch 2001). For example, in stand reconstructions across an extensive area in northwest Utah, central Nevada, southwest Idaho, and southeast Oregon, extant and dead trees dating to the period before 1860 were found in only $16-67 \%$ of current woodland stands, suggesting that the current area occupied by trees has increased $150-625 \%$ since 1860 (Miller et al. 2008).
In that study, old trees ( $>140 \mathrm{yr}$ ) were usually scattered in low densities across the landscape with no evidence that pre-1860 stands were as dense as many stands today. In another study, old trees ( $>140 \mathrm{yr}$ ) accounted for $<10 \%$ (usually $<2 \%$ ) of the individuals that were $>30 \mathrm{~cm}$ in height (Johnson and Miller 2007). Similarly, Gedney et al. (1999) compared US Forest Service surveys conducted in 1938 and 1988 across eastern Oregon and reported a $600 \%$ increase in area occupied by $\mathrm{J}$. occidentalis. Rates of increase in tree cover are very fast in some areas, e.g., ca. $10 \% \cdot$ decade $^{-1}$ (Weisberg et al. 2007) or even a doubling every $30 \mathrm{yr}$ (Soulé et al. 2004). Bauer (2006) observed a sharp increase in the rate of tree establishment beginning in ca. 1880, when the stem-density doubling interval decreased from $85 \mathrm{yr}$ to $45 \mathrm{yr}$. Expansion of trees into former shrublands is occurring extensively on more productive, mesic sites, along with infill of old woodlands on less-productive, drier sites (Weisberg et al. 2007). However, there is geographic variability in the initiation and rate of increase in density: for example, across six woodland stands in the northern portion of the Great Basin, tree age structures revealed a gradual shift from substantial increases in piñon and junipers through the middle 20th century to relatively limited establishment at the end of the century (Miller et al. 2008).

Moving to the Colorado Plateau, age reconstructions in northern Arizona document infill of persistent woodlands on three common soil types (Landis and Bailey 2005). Infill of persistent woodlands and wooded shrublands and expansion of piñon and juniper into shrublands is also occurring locally on portions of the Uncompahgre Plateau and Mesa Verde in southwestern Colorado (Eisenhart 2004; Floyd et al. 2004; Shinneman and Baker 2009). Most of the infill on the Uncompahgre Plateau is by $P$. edulis (Shinneman and Baker 2009). Despite the local occurrence of infill and expansion in this region, net change in tree density and coverage at a broad landscape level has been minimal (Manier et al. 2005). Further evidence that the actual change in vegetation structure in this region has been relatively minor overall comes from photographs of Mesa Verde taken in the late 1800s (e.g., Chapin 1892), which show dense woodlands similar in appearance to those of today, and descriptions of dense tree cover in written reports from the early 20th century-e.g., Cary (1911):

A very dense growth of pinyon covers the Mesa Verde and practically all the broken country from Montezuma County north to Mesa County. A heavy and continuous belt is found on the lowest flanks of all the mountains from the San Juans north to the Book Cliffs... (p. 216)

Extensive infill of former savannas and expansion of trees (especially J. monosperma) into former grasslands are well documented in New Mexico and Arizona by written and oral accounts (Leopold 1924, 1951), by aerial and ground-based repeat photography (e.g., Sallach 1986; Miller 1999; Fuchs 2002), and by tree age structure analyses (Jacobs et al. 2008). For example, a comparison of aerial photos of a southwestern New Mexico study area revealed that former grasslands and juniper savannas had been largely replaced by relatively dense stands of $J$. deppeana, such that forests and woodlands having $>40 \%$ tree canopy cover comprised $<50 \%$ of the 
landscape in 1935 but had risen to $>80 \%$ by 1991 (Miller 1999).

An important management question is whether any particular woodland on the landscape today has long been occupied by trees-either as persistent woodland or savanna or wooded shrubland-or represents a former grassland or shrubland that has been converted to woodland via tree expansion during the past $150 \mathrm{yr}$. A variety of methods is available for answering this question, although each method has inherent limitations. Aerial-based and ground-based repeat photography is a powerful tool if available, but we lack historic photo coverage for much of the West. Visual and rephotographic sources also have limited ability to distinguish among changes in tree density, tree size, and canopy cover. For instance, resampling of permanent plots showed that a visually apparent increase in tree cover did not represent a substantial density increase, but primarily reflected enlarging of tree canopies as trees age (Ffolliott and Gottfried 2002). Age structure analysis based on tree rings also provides powerful insights into stand history, although this method is expensive and time-intensive. An age structure composed entirely of young trees, coupled with an absence of large dead boles, stumps, or other evidence of past disturbance by fire or wood harvest, indicates that a site was not wooded for at least a few centuries before the establishment of the extant trees (Jacobs et al. 2008).

Data from both photos and tree rings are limited to only the past one to several centuries because of the availability of the technology and the gradual loss of older trees over time (the "fading record"; Swetnam et al. 1999). A longer-term view of vegetation change over centuries or millennia can be obtained from pack rat (Neotoma spp. Say and Ord, 1825) middens, which often contain plant materials collected and preserved through millennia. It must be recognized, however, that midden data indicate only the presence or absence of plant species; they do not tell us much about abundance (Lyford et al. 2004). Moreover, pack rats tend to collect vegetation in the rocky areas around their nests, so middens may not reflect changes occurring in areas far away from the rocks where some of the most dramatic recent tree expansion appears in photographic comparisons (Swetnam et al. 1999). One of the strongest forms of evidence that a local area was persistently occupied by grassland, shrub-grassland, or low-density savanna in the past is the presence of a mollic epipedon, which typically develops where grasses are a dominant vegetation component over long periods. However, in some areas the upper soil horizons have been entirely lost through previous erosion (sometimes as a consequence of poor grazing practices), thus complicating accurate soils interpretations (Romme et al. 2008).

A novel indicator of former sagebrush communities is the presence of sage-grouse (Centrocercus urophasianus Bonaparte, 1827) leks. Some areas of current woodland are documented to have supported sage-grouse populations in the late 1800s and early 1900s. Sage-grouse hens renest in the same general sagebrush-dominated areas year after year, and their mature offspring do the same; colonization of new areas is slow (Dunn and Braun 1985; Hanf et al. 1994; Connelly et al. 2004; Schroeder and Robb 2004). Thus, documented past use by sage-grouse in a woodland today is evidence that the woodland has developed within a former sagebrush community.
Statement 6: Mechanisms for Increasing Density and Expansion The mechanisms underlying increasing tree density in existing piñon and juniper woodlands and the expansion of piñon and juniper into grasslands and shrublands are not well understood in most situations. Possible mechanisms include recovery from past, severe disturbance; natural, ongoing, Holocene range expansion; livestock grazing; fire exclusion; and effects of climatic variability and rising atmospheric $\mathrm{CO}_{2}$. Fire exclusion cannot be the principal mechanism in persistent woodlands because fires were never frequent in these ecosystems, but in general, there is much uncertainty about the ecological processes driving tree-density increases in any particular location. The evidence for and against each of these potential mechanisms is evaluated in section III of this article.

Applicability and Confidence. The major ecological processes that underlie documented increases in tree density probably vary among geographic locations and types of piñon and juniper vegetation and may also have varied during the course of the past 150 yr. Although local ecological history and mechanisms of change have been well documented in some areas, for most locations the relative importance of the potential drivers of increasing tree density is unknown. Rigorous testing of the potential mechanisms discussed in section III of this article should be a high-priority topic for research.

\section{III: EVALUATING THE MECHANISMS OF INFILL AND EXPANSION}

A pattern of increasing tree density in many persistent woodlands, savannas, and wooded shrublands and of tree expansion into many former grasslands and shrublands, is well documented (statement 5 in section II, above). However, the mechanisms driving these changes are unclear. This is an important issue, because infill and expansion are often attributed primarily to effects of fire exclusion; consequently vegetation treatments designed to reduce or eliminate piñons and junipers are often justified in part by the assumption that past and present land uses have produced "unnatural" increases in tree density. Although this assumption is probably correct in some situations, clearly, it is not correct in all. For example, exclusion of low-severity surface fires during the 20th century cannot be the primary reason for infill of persistent woodlands, because low-severity fire was never frequent in these ecosystems, even before EuroAmerican settlement (statement 1). Furthermore, in many places, we can explain increasing tree density as recovery from severe fire or anthropogenic clearing in the past or as natural range expansion near the biogeographical limits of a tree species. Therefore, we begin this section by reviewing these two "normal" and relatively well-understood mechanisms for increases in local tree density or extent (i.e., recovery from past severe disturbance and natural range expansion).

But what is driving the infill of persistent woodlands, savannas, and wooded shrublands, and expansion of piñon and juniper into former grasslands and shrublands, in the many places across the West, where there is no evidence of earlier 
severe fire or clearing and where infill and expansion are occurring near the center of the species' biogeographical distributions? In the sections below, we evaluate the three most cogent explanations that have been offered for these patterns: 1) direct and indirect effects of livestock grazing, 2) fire exclusion, and 3) effects of climatic variability and rising atmospheric $\mathrm{CO}_{2}$. Surprisingly little empirical or experimental evidence is available to support or refute any of these hypotheses; most interpretations are based on logical inference. Consequently, we cannot now come to any firm conclusions about the mechanisms driving infill and expansion of piñon and juniper in many locations. Nevertheless, we review existing evidence and data gaps for each of these three hypotheses, and we stress that this question is a high-priority research topic for piñon-juniper vegetation in general.

\section{Recovery From Past Severe Disturbance}

Although fires are infrequent in most piñon and juniper woodlands, large, severe fires do occur under some weather conditions (Fig. 3), and recovery of the former woodland structure requires many decades to centuries (e.g., Erdman 1970; Floyd et al. 2000, 2004). Evidence of a stand-replacing fire will remain conspicuous for many decades or centuries in the form of charred snags and downed wood. Thus, a stand of young piñons or junipers growing amidst charred juniper snags and other forms of partially burned wood is not testimony to undesirable effects of fire exclusion but simply represents recovery from a past high-severity fire.

Similarly, many areas that were chained in the 1950s and 1960s now support dense stands of young piñons or junipers that can give the appearance of expansion into grasslands or shrublands (e.g., Paulson and Baker 2006:143-146); however, closer inspection often reveals windrows of large, dead tree boles that were piled up during the chaining operation, along with stumps and seeded nonnative grasses. Such a stand of young trees does not represent abnormal expansion of trees into nonwoodland habitats but is another example of natural recovery from severe disturbance. Widespread harvest also occurred during the Euro-American settlement era to provide materials for fence posts, firewood, construction materials, and charcoal to support the mining industry, e.g., in the Nevada Great Basin, (Young and Budy 1979) and in territorial New Mexico (Scurlock 1998:128-129). Sallach (1986) interpreted 20th century increases in tree density in many places in New Mexico as recovery of preexisting woodlands following severe human disturbance (wood-cutting and clearing for pasture improvement) rather than infill or invasion of previously sparse woodlands and grasslands. In some portions of the Southwest, woodlands may still be recovering from centuries of deforestation and other land uses by prehistoric and historic Puebloan peoples (Wyckoff 1977; Samuels and Betancourt 1982; Kohler and Matthews 1988; Allen et al. 1998; Allen 2004:64-66; Briggs et al. 2007).

Unfortunately, the extent, intensity, and specific locations of historic and prehistoric fire, harvest, and clearing are not generally well known. Nevertheless, particularly if a burned or cleared stand was a persistent woodland, then local site conditions are inherently favorable for trees, and we should expect trees to reestablish naturally on the disturbed site.

\section{Natural Range Expansion}

The presence of young piñon and juniper trees near the species' current geographical range limits may represent natural, longterm change in biogeographical extent, rather than unnatural expansion into nonwoodland habitats. Studies of subfossil pollen deposits and pack rat middens reveal that many lowelevation conifer species, including junipers, piñons, and ponderosa pine, have been expanding their ranges throughout the Holocene (the past $\sim 12000 \mathrm{yr}$ ) from glacial refugia in the Southwest and in northern Mexico. In response to increasing temperatures and perhaps aided by moist periods, piñons expanded rapidly into the central and northern parts of the western United States at the end of the Pleistocene (Betancourt 1987; Nowak et al. 1994; Swetnam et al. 1999; Wigand and Rhode 2002), whereas junipers may have expanded with increasing temperatures but during drier periods (Lyford et al. 2003).

This natural range expansion continues today. For example, the northernmost $P$. edulis population in eastern Colorado, near Fort Collins, has been present for only about 400-500 yr, and piñon continues to increase and expand into adjacent shrub and grassland communities (Betancourt et al. 1991). Similarly, the northernmost outlier of $P$. edulis in northeastern Utah, at Dutch John Mountain, was colonized as recently as the 1200 s (Gray et al. 2006). J. osteosperma has also been expanding its range in Wyoming and in adjacent sites in Utah and Montana for the past several thousand years, both at a regional scale by moving into new mountain ranges and at local scales by expanding populations where it was already established. In fact, juniper populations in some parts of Wyoming may represent the first generation of trees in these areas (Lyford et al. 2003). In addition to latitudinal range expansions following the Pleistocene, piñons and junipers have moved to higher or lower elevations in response to the climate changes that have occurred during the Holocene; for example, woodlands in the Great Basin have alternately expanded across large areas of the landscape during favorable climatic periods and retreated to smaller refuge areas during less-favorable periods (Miller and Wigand 1994). Thus, some expansions (and contractions) of piñons and junipers represent the species' responses to natural processes, such as climate change, rather than a consequence of land use or other human activities.

Unfortunately, not all of the specific locations where natural biogeographic range expansion is occurring have been mapped. Nevertheless, this mechanism should be considered in local site evaluations, especially where a site is located near the margins of the species' range.

\section{Direct Effects of Livestock Grazing}

Extensive livestock grazing began in the late 1800s in many parts of the western United States (Wooton 1908; Oliphant 1968; Dahms and Geils 1997; Scurlock 1998; Allen et al. 2002; Hessburg and Agee 2003), and extensive infill and expansion of piñon and juniper began at the same time in many areas (e.g., Miller and Rose 1999; Fuchs 2002; Landis and Bailey 2005; C. D. Allen, unpublished data, 2008). The coincidence in time between the onset of grazing and the increasing of tree density suggests a direct cause-effect relationship. Two mechanisms may be involved. First, heavy grazing may reduce herbaceous 
competition with tree seedlings and thereby enhance seedling survival. Support for this mechanism comes from the Johnsen (1962) report of markedly better growth of juvenile $J$. monosperma in places where grass had been removed. Second, heavy grazing often leads to an increase in density and cover of shrubs, which may serve as "nurse plants" for tree seedlings (Floyd 1982; Soulé et al. 2004).

However, empirical evidence for or against the grazing mechanism is sparse and mixed. Density of tree seedlings and saplings (mostly $P$. edulis) was nearly three times greater in grazed areas than in ungrazed reference sites on the Uncompahgre Plateau in western Colorado (Shinneman and Baker 2009). In contrast, Harris et al. (2003) reported comparable 20th century increases in density of $P$. edulis and $J$. osteosperma in both grazed and ungrazed areas in a southern Utah study site, and Burkhardt and Tisdale (1976) found no relationship between range condition (reflecting past grazing intensity) and rate of expansion by $J$. occidentalis in southwestern Idaho. A comparison of four minimally grazed sites with nearby heavily grazed sites in central Oregon revealed dramatic increases in canopy cover of $J$. occidentalis between the 1960s and the 1990s in both the grazed and ungrazed areas. Although the increase was greater in the grazed sites, the dramatic rate of young tree establishment in long-ungrazed sites led to the conclusion that grazing was not the major driver for tree infill and expansion in the region (Knapp and Soule 1996; Soulé and Knapp 1999, 2000; Soulé et al. 2003). Observers often note anecdotally that lightly grazed areas appear to contain as many young trees as heavily grazed areas, e.g., in the northern Great Basin (R. F. Miller, personal observation) and in south-central New Mexico (E. H. Fuchs, personal communication, March 2007).

It is well known that grazing effects can be extremely variable across different soil types within the same climatic zone. For example, McAuliffe (2003) noted that grazed soil types with shallow argillic horizons are much more resistant to woody plant encroachment than are sites that promote deeper infiltration, and Burkhardt and Tisdale (1976:481) commented that physical soil characteristics appeared to influence juniper establishment and growth more than vegetational characteristics influenced by grazing. Moreover, the mechanistic relationship between herbaceous competition and tree seedling establishment has received little experimental testing beyond the early Johnsen (1962) study.

Thus, we simply lack adequate empirical or experimental information with which to confidently evaluate the importance (or lack of importance) of the direct effects of livestock grazing as a key mechanism driving tree infill and expansion during the past $150 \mathrm{yr}$. However, the indirect effect of livestock grazing may also have been important because sustained heavy grazing reduces grasses and other herbaceous fuels, thus reducing fire spread under both modal and extreme fire weather conditions (Fig. 3). In some western ponderosa pine and dry mixed-conifer forests, exclusion of low-severity fires has been a principal mechanism driving tree density increases during the 20th century (e.g., Allen et al. 2002; Hessburg and Agee 2003), although, in other western ponderosa pine forests, the principal mechanisms were 19th century fires, logging, and livestock grazing, rather than fire exclusion (Baker et al. 2007). Thus, the importance of this indirect effect of grazing hinges on the importance of fire exclusion in driving infill and expansion of piñons and junipers (next section below).

\section{Fire Exclusion}

Fire exclusion cannot be the principal mechanism responsible for infill of persistent woodlands because fires were never frequent in these ecosystems (statements $1-3$ in section II above). However, a logical argument can be made that fire exclusion since the mid-1800s is a primary cause of piñon and juniper infill in savannas and wooded shrublands and of tree expansion into former grasslands and shrublands. Southwestern savannas and grasslands, in particular, often produce continuous fine fuels conducive to frequent and wide-spreading fires, and they occur in regions where wet/dry climatic cycles are common. Thus, it is logical to hypothesize that historical fires in these ecosystems were frequent enough to kill most of the fire-intolerant piñons and junipers that continually became established among the fire-tolerant grasses. Fire behavior and effects in wooded shrublands (especially those with tall shrubs) differ from fire in savannas in that the shrub fuels typically support higher flame lengths, greater heat release, and greater likelihood of extensive tree mortality (Fig. 3), and postfire recovery of the shrubs is often slower than recovery of burned grasses. Nevertheless, in both kinds of ecosystems recurrent fires may have maintained tree densities well below what could potentially be supported by local climate and soils; higherdensity stands may have persisted only in relatively fire-safe sites, such as on rocky outcrops or in rocky draws, where fire spread or high-severity fire was inhibited. Support for the fireexclusion hypothesis comes from the extensive infill and expansion that began to occur in many places in the late 19th century, coincident with the onset of livestock grazing and the resulting reduction in the frequency of extensive surface fires. Grazing intensity was greatly reduced in most of the West after 1930, but effective governmental fire suppression began to be more effective at about that time (Pyne 1982), and additional land use changes-notably those resulting in fragmentation of landscapes, including roads, buildings, and cleared fields-have generally precluded the extensive fires that may have burned before the late 19th century in many areas.

Although this interpretation is logical, it has a major empirical shortcoming - namely, that the assumption of frequent historical fires is unproven (even untested) in many areas. In the relatively few fire history studies that have been conducted in piñon and juniper vegetation, fire-scarred trees (perhaps the most conclusive direct evidence of past fires) are typically rare or absent (Baker and Shinneman 2004). There are questions about how to interpret the paucity of fire-scarred piñons and junipers (see the research priorities section in Romme et al. 2008), but a general lack of fire scars is consistent with the idea that fires were actually infrequent in all or most kinds of piñon and juniper vegetation in the past. If fire was in fact infrequent in piñon and juniper vegetation before the late 1800 s, then fire exclusion cannot be the major driver of tree infill and expansion during the last $150 \mathrm{yr}$. Thus, we see that two logical, but contradictory, interpretations can be made about the historical role (or lack of a role) of fire in limiting piñon and juniper infill and expansion. To critically evaluate both interpretations, we need more spatially extensive empir- 
ical data on piñon-juniper fire history, especially in piñon and juniper savannas where the hypothesis of historically frequent fire is perhaps most compelling based on fuel structure and climate.

In the absence of adequate empirical data, interpretations of fire history are often based instead on anecdotal observations and logical inference. There is also a tendency to import observations from areas of very different biophysical conditions and treat them as generalities when data are sparse. For example, late 19th century fires in some desert grasslands of southeastern Arizona are documented from newspaper accounts (Bahre 1991:138-141), and it is also logically inferred that fires must have been relatively frequent to prevent shrub encroachment of some desert grasslands (McPherson 1995). One might assume from this evidence that fire played a similar role in desert grasslands, piñon and juniper savannas, and open woodlands that have grassy understories, throughout much of the Southwest. However, desert grasslands in Arizona differ in composition and climate from those in New Mexico, and grasslands at the edge of the Great Plains in eastern New Mexico differ yet again. Moreover, Wright (1980:16) states that the pre-1900 role of fire in grasslands of southern Arizona and New Mexico is simply unknown and that fire was possibly unimportant ecologically in at least some kinds of desert grassland, e.g., black grama (Bouteloua eriopoda [Torr.] Torr.) communities. We have a similarly inadequate understanding of the (probably complex) ecological role of fire in piñon and juniper savannas of Arizona and New Mexico.

A similar paucity of empirical fire history data plagues our efforts to understand what is driving tree infill and expansion in sagebrush-dominated communities and associated wooded shrublands of the Great Basin and Colorado Plateau. Weisberg et al. (2008) tested the hypothesis that old-growth woodlands (predating the mid-1800s) in central Nevada were generally absent from topographic sites having high probabilities of burning and were largely restricted to sites with low probability of burning. If true, this pattern would be consistent with the idea that fire formerly limited trees to fire-safe locations and that fire exclusion was a major driver of tree expansion into nonwoodland vegetation types that formerly remained treeless because of frequent fires. Although Weisberg et al. (2008) found that old-growth stands were indeed more likely to occur on sites determined to be of low fire risk, the relationships were weak overall, and many old-growth stands were located on sites of relatively high fire risk from a topographic perspective. Thus, the study provided only somewhat ambiguous support for the fire-exclusion hypothesis.

Following another line of investigation, historical fire rotations (time required for cumulative area burned to equal the size of the entire area of interest) in Wyoming big sagebrush (Artemisia tridentata Nutt. subsp. wyomingensis Beetle \& Young) and little sagebrush (Artemisia arbuscula Nutt.), which formed the matrix within which many of the woodland communities existed, are estimated to have been 100-450 yr (Baker 2006). With such long rotations, it would seem that fire was not frequent enough historically to prevent extensive tree establishment and that the long fire intervals observed during the 20th century are not far outside the historical range of fire intervals-all implying that fire exclusion cannot be the major driver of piñon and juniper infill and expansion. However, the sagebrush community is very heterogeneous, and a single, broad characterization of historical fire rotations cannot adequately convey the complex historical role of fire in these ecosystems. For example, historical fire rotations were substantially shorter in the more mesic mountain big sagebrush (Artemisia tridentata Nutt. subsp. vaseyana [Rydb.] Beetle) communities than in the more xeric Wyoming big sagebrush and little sagebrush communities (Miller and Rose 1999; Baker 2006), and conversion of shrubland to woodland can also occur more rapidly (within only several decades) in the more mesic habitats (Miller and Rose 1999; Johnson and Miller 2006)-suggesting that the late 19th- and 20th-century reduction in fire frequency was in fact a major cause of tree expansion in at least some shrublands.

In sum, we simply do not have adequate empirical data on historical fire regimes to determine how important (or unimportant) fire exclusion has been in allowing infill and expansion of piñon and juniper trees in savannas and wooded shrublands across the West. Obtaining additional fire history data is, therefore, a high research priority (Romme et al. 2008).

\section{Effects of Climatic Variability and Rising $\mathrm{CO}_{2}$}

The onset of extensive infill and expansion of piñon and juniper in the late 19th century in many areas coincided not only with the beginning of grazing and fire exclusion but also with a significant climatic event, namely, the end of the Little Ice Age and the beginning of a general warming trend with changes in precipitation patterns that continued through the 20th century. Many years in the early 1900s were notably wet throughout the Southwest, and the last four decades of the 20th century were among the wettest in the period of record (Gray et al. 2004). Occupying, as they do, the transition zone between mesic forests at higher elevations and environments too dry for trees at lower elevations, piñon-juniper communities may be especially sensitive to even subtle changes in temperature and precipitation.

It is possible that some, or even much, of the infill and expansion of piñon and juniper that has occurred during the past $150 \mathrm{yr}$ is a natural response to short-term and long-term climatic fluctuation. Two long-term 20th century data sets from desert and semidesert areas of southern New Mexico and Arizona reveal that relatively high winter precipitation generally favors woody plants over herbaceous species and that specific periods of extensive shrub establishment coincided with periods of wet winters (Neilson 1986; Brown et al. 1997). These two studies focused primarily on expansion of shrubs, not trees, but other studies demonstrate that recovery of woodlands from drought may occur as a pulse of $P$. edulis recruitment during the first wet period that follows the drought (Swetnam et al. 1999; Gray et al. 2006; Shinneman and Baker 2009). For example, in two study areas on the Uncompahgre Plateau in western Colorado, piñon abundance began increasing in the late 1700s during a wet period that followed a long dry period (Eisenhart 2004; Shinneman and Baker 2009). Tree infill and expansion in this area thus began more than half a century before arrival of Euro-American settlers and associated effects of livestock grazing and fire exclusion. In the 20th century, there were two very wet periods in the Southwestduring the first two decades of the century and the period from 
the mid-1970s to the mid-1990s (Swetnam and Betancourt 1998). These are both periods when many piñon trees became established in the region (e.g., Floyd et al. 2004).

Additional support for the climate hypothesis comes from observations of recent contraction, as well as expansion, of piñon and juniper woodlands. Although much of the 20th century was apparently favorable for tree establishment and survival, extensive $P$. edulis mortality occurred in the Southwest during severe droughts of the 1950s and from the mid-1990s through the early 2000s (statement 2 in section II above).

Extensive recruitment of $J$. occidentalis that began in Oregon during the late 1800s and early 1900s also coincided with a climatically favorable period of relatively high winter precipitation (Soulé et al. 2004). Tree density and cover have continued to increase throughout the 20th century in this region, both on grazed and ungrazed sites (Soulé et al. 2003, 2004). During the late 20th and early 21st centuries, however, radial growth rates of $J$. occidentalis have increased more than would be predicted from climate variables alone, with exceptional growth rates during both wet and dry periods (Knapp et al. 2001). Predictions of ring growth during the past $100 \mathrm{yr}$ were improved in regression models that included global atmospheric $\mathrm{CO}_{2}$ concentration in addition to precipitation and temperature (Knapp and Soulé 2008). These results are consistent with a $\mathrm{CO}_{2}$ fertilization effect that may be enhancing the processes of tree infill and expansion throughout the West. Elevated $\mathrm{CO}_{2}$ in experimental settings often results in proliferation of fine roots, increased instantaneous transpiration efficiency and water use efficiency, and decreased stomatal conductance, all of which potentially could make plants more resistant to drought and enhance growth rates under dry conditions (Wullschleger et al. 2002).

A major shortcoming of the climate hypothesis is that the evidence is mostly correlative, with limited experimental data with which to evaluate the specific mechanisms by which piñons and junipers respond to specific climatic changes. Although research to date has demonstrated some important physiological differences among the major piñon and juniper species (e.g., Moore et al. 1999; Nowak et al. 1999), we have barely begun to assess the species' ecophysiology within the context of climate change and rising $\mathrm{CO}_{2}$. For example, Wullschleger et al. (2002) emphasize that there is much uncertainty about the mechanisms by which increased atmospheric $\mathrm{CO}_{2}$ might alter water relations and growth and about the significance of these changes for total plant growth and survival. We also have a poor understanding of how climatic variability influences growth and abundance of the herbaceous component of piñon and juniper vegetation, notably grasses, which in turn influence fuel structure and potential fire behavior.

\section{Summary of Potential Mechanisms Driving Tree Infill and Expansion}

It is widely assumed that infill and expansion of piñon and juniper represent primarily an "unnatural" consequence of human land use, in particular the effects of fire exclusion. It is important to stress, however, that human land use in the western United States since the mid to late 1800s has occurred against a backdrop of climatic and natural disturbance-driven fluctuations in tree establishment and survival. All of these processes interact, and the relative importance of each (e.g., direct grazing impacts vs. fire exclusion vs. climatic fluctuation vs. $\mathrm{CO}_{2}$ fertilization) probably varies spatially and temporally across the vast expanse of heterogeneous environments occupied by piñon and juniper vegetation. Soulé et al. (2004) suggest that the early pulse of $J$. occidentalis establishment in Oregon during the late 19th and early 20th centuries was driven primarily by favorable climatic conditions, grazing effects, and fire exclusion, whereas the late 20th century increase in tree cover and density has been primarily a response to elevated atmospheric $\mathrm{CO}_{2}$ and biological inertia (the increase in seed production as trees that established earlier in the century reach reproductive age and greater size). Similar changes over time in the dominant mechanisms may be important in other regions and for other piñon and juniper species. The upshot is that simplistic and overgeneralized explanations of the processes driving infill and expansion should be avoided, and new research is urgently needed to disentangle the relative effects of the various mechanisms underlying piñon and juniper infill and expansion in different ecoregions throughout the western United States during various segments of the past $150 \mathrm{yr}$ (Romme et al. 2008).

\section{IMPLICATIONS}

Effective management of piñon and juniper vegetation has been hindered by inadequate understanding of the basic ecology of these ecosystems, notably 1) the variability in ecosystem structure and processes that exists among the diverse combinations of piñons, junipers, and associated shrubs, herbs, and soil organisms throughout this extensive vegetation type; 2) prehistoric and historic disturbance regimes; and 3) mechanisms driving recent changes in vegetation structure and composition. This article summarizes what we currently know (and don't know) about three fundamentally different kinds of piñon-juniper vegetation-persistent woodlands, savannas, and wooded shrublands. Historical structure and disturbance regimes are perhaps best understood for persistent woodlands, although the geographic distribution of such woodlands is uncertain, especially in New Mexico and Arizona. In contrast, historical disturbance regimes in piñon-juniper savannas are the least well understood of the three piñon-juniper types. Dramatic tree expansion and infill have occurred during the past $150 \mathrm{yr}$ in portions of all three types of piñon-juniper vegetation, although equally dramatic mortality events have also occurred recently in some areas. The potential mechanisms driving increases in tree density-notably recovery from past disturbance, natural range expansion, livestock grazing, fire exclusion, climatic variability, and elevated atmospheric $\mathrm{CO}_{2}-$ generally have not received enough empirical or experimental investigation to predict which is most important in any given location. We recommend that land managers, practitioners, and policy makers rely primarily on this article's statements of high confidence and broad applicability in formulating management plans and priorities, and we encourage researchers to conduct new studies to critically test the statements of moderate or low confidence and generality. In particular, we 
encourage collaboration between research scientists and managers in current and upcoming piñon-juniper treatments.

\section{ACKNOWLEDGMENTS}

We appreciate the encouragement and advice given by Ayn Shlisky, Mike Babler, Anne Bradley, and Lynn Decker of The Nature Conservancy and by Dan Binkley of Colorado Forest Restoration Institute throughout the process of preparing the article. We also appreciate the field trips and discussions about New Mexico's piñon-juniper vegetation with Hollis Fuchs, Sid Goodloe, and Steven Yanoff.

\section{LITERATURE CITED}

Allen, C. D. 1989. Changes in the landscape of the Jemez Mountains, New Mexico. [dissertation]. Berkeley, CA, USA: University of California. $346 p$.

ALLen, C. D. 2004. Ecological patterns and environmental change in the Bandelier landscape. In: T. A. Kohler [ED.]. Village formation on the Pajarito Plateau, New Mexico: archaeology of Bandelier National Monument. Albuquerque, NM, USA: University of New Mexico Press. p. 19-68.

Allen, C. D., J. L. Betancourt, and T. W. Swetnam. 1998. Landscape changes in the southwestern United States: techniques, Iong-term data sets, and trends. In: T. D. Sisk [ED.]. Perspectives on the land use history of North America: a context for understanding our changing environment. Reston, VA, USA: US Geological Survey, Biological Science Report USGS/BRD/BSR1998-0003. p. 71-84.

Allen, C. D., M. Savage, D. A. Falk, K. F. Suckling, T. W. Swetnam, T. Schulke, P. B. Stacey, P. Morgan, M. Hoffman, and J. T. Klingel. 2002. Ecological restoration of southwestern ponderosa pine ecosystems: a broad perspective. Ecological Applications 12:1418-1433.

BAHRE, C. J. 1991. A legacy of change: historic human impact on vegetation in the Arizona Borderlands. Tucson, AZ, USA: University of Arizona Press. $231 \mathrm{p}$.

BAKer, W. L. 2006. Fire and restoration of sagebrush ecosystems. Wildlife Society Bulletin 34:177-186.

Baker, W. L., and D. J. Shinneman. 2004. Fire and restoration of pinyon-juniper woodlands in the western United States: a review. Forest Ecology and Management 189:1-21.

Baker, W. L., T. T. Veblen, and R. L. SherRifF. 2007. Fire, fuels and restoration of ponderosa pine-Douglas fir forests in the Rocky Mountains, USA. Journal of Biogeography 34:251-269.

BAUER, J. 2006. Fire history and stand structure of a central Nevada pinyon-juniper woodland [thesis]. Reno, NV, USA: University of Nevada, Reno. 143 p.

Betancourt, J. L. 1987. Paleoecology of pinyon-juniper woodlands: summary. In: R. L. Everett [ED.]. Proceedings-Pinyon-Juniper Conference; 13-16 January 1986; Reno, NV, USA. Ogden, UT, USA: US Department of Agriculture, Forest Service, Intermountain Research Station, General Technical Report INT-215. p. 129-139.

Betancourt, J. L., E. A. Pierson, K. Aasen-Rylander, J. A. Fairchild-Parks, and J. S. Dean. 1993. Influence of history and climate on New Mexico pinyonjuniper woodlands. In: E. F. Aldron and D. W. Shaw [EDS.]. Managing pinyonjuniper ecosystems for sustainability and social needs: proceedings of the symposium; 26-30 April 1993; Santa Fe, NM, USA. Washington, DC, USA: US Department of Agriculture, Forest Service, General Technical Report RM-236. p. 42-62.

Betancourt, J. L., W. S. Schuster, J. B. Mitton, and R. S. Anderson. 1991. Fossil and genetic history of a pinyon pine (Pinus edulis) isolate. Ecology 72:1685-1697.

Breshears, D. D., N. S. Сobb, P. M. Rich, K. P. Price, C. D. Allen, R. G. Balice, W. H. Romme, J. H. Kastens, M. L. Floyd, J. Belnap, J. J. Anderson, O. B. Myers, AND C. W. MeYer. 2005. Regional vegetation die-off in response to globalchange-type drought. Proceedings of the National Academy of Sciences 102(42):15144-15148.

Briggs, J. M., H. SchaAfsma, and D. Trenkov. 2007. Woody vegetation expansion in a desert grassland: prehistoric human impact? Journal of Arid Environments 69:458-472.
Brown, J. H., T. J. Valone, and C. G. Curtin. 1997. Reorganization of an arid ecosystem in response to recent climate change. Proceedings of the National Academy of Sciences 94(18):9729-9733.

Brown, P. M., M. W. Kaye, L. S. Huckaby, and C. H. Baisan. 2001. Fire history along environmental gradients in the Sacramento Mountains, New Mexico: influences of local patterns and regional processes. Ecoscience 8:115-126.

Burkhardt, J. T., and E. W. Tisdale. 1976. Causes of juniper invasion in southwestern Idaho. Ecology 57:472-484.

Camp, A., H. M. Poulos, R. Gatewood, J. Sirotnak, and J. Karges. 2006. Assessment of top down and bottom up controls on fire regimes and vegetation abundance and distribution patterns in the Chihuahuan Desert Borderlands: a hierarchical approach-unpublished final report to the Joint Fire Sciences Program, Project 03-3-3-13. New Haven, CT, USA: Yale University. $77 \mathrm{p}$.

CaRY, M. 1911. A biological survey of Colorado. Washington. DC, USA: US Department of Agriculture Bureau of Biological Survey, North American Fauna Series 33. $256 \mathrm{p}$.

Chapin, F. H. 1892. The land of the cliff-dwellers. Boston, MA, USA: W.B. Clark and Co. for Appalachian Mountain Club, Reprinted in 1988. Tucson, AZ, USA: University of Arizona Press. $188 \mathrm{p}$.

Connelly, J. W., S. T. Knick, M. A. Schroeder, and S. J. Stiver. 2004. Conservation assessment of the great sage-grouse and sagebrush habitats. Cheyenne, WY, USA: Western Association of Western Wildlife Agencies. 610 p. Available at: http://gf.state.wy.us/downloads/pdf/GreaterSGConservationAssessment.pdf. Accessed 12 April 2009.

Dahms, C. W., and B. W. Gells (TECH EDS.). 1997. An assessment of forest ecosystem health in the Southwest. Washington, DC, USA: US Department of Agriculture, Forest Service, General. 2002. Technical Report RM-GTR-295. 97 p.

Dunn, P. O., AND C. E. Braun. 1985. Natal dispersal and lek fidelity of sage grouse. Auk 102:621-627.

EISENHART, K. S. 2004. Historic range of variability and stand development in piñon-juniper woodlands of western Colorado [dissertation]. Boulder, CO, USA: University of Colorado, Boulder. $255 \mathrm{p}$.

ERdman, J. A. 1970. Pinyon-juniper succession after natural fires on residual soils of Mesa Verde, Colorado. Brigham Young University Science Bulletin. Biological Series 11(2):1-26.

Ffolliott, P. F., And G. J. Gottfri Dynamics of a pinyon-juniper stand in northern Arizona: a half-century history. Fort Collins, CO, USA: US Department of Agriculture, Forest Service, Rocky Mountain Research Station, Research Paper RMRS-RP-35. $12 \mathrm{p}$.

FLoYD, M. E. 1982. Interaction of piñon pine and Quercus gambelii in succession near Dolores, Colorado. Southwestern Naturalist 27:143-147.

Floyd, M. L., M. Colyer, D. D. Hanna, and W. H. Romme. 2003. Gnarly old trees: canopy characteristics of old-growth piñon-juniper woodlands. In: M. L. Floyd [ED.]. Ancient piñon-juniper woodlands. Boulder, CO, USA: University Press of Colorado. p. 11-30.

Floyd, M. L., D. D. Hanna, and W. H. Romme. 2004. Historical and recent fire regimes in piñon-juniper woodlands on Mesa Verde, Colorado, USA. Forest Ecology and Management 198:269-289.

Floyd, M. L., W. H. Romme, and D. Hanna. 2000. Fire history and vegetation pattern in Mesa Verde National Park. Ecological Applications 10:1666-1680.

Floyd, M. L., W. H. Romme, D. D. Hanna, M. Winterowd, D. Hanna, and J. Spence. 2008. Fire history of piñon-juniper woodlands on Navajo Point, Glen Canyon National Recreation Area. Natural Areas Journal 28(1):26-36.

FucHs, E. H. 2002. Historic increases in woody vegetation in Lincoln County, New Mexico. Albuquerque, NM, USA: Vanguard Printing Company. 115 p.

Gedney, D. R., D. L. Azuma, C. L. Bolsinger, and N. McKay. 1999. Western juniper in eastern Oregon. Portland, OR, USA: US Department of Agriculture, Forest Service, General Technical Report NW-GTR-464. 53 p.

Gilleet, N. P., A. J. Weaver, F. W. Zwiers, and M. D. Flannigan. 2004. Detecting the effect of climate change on Canadian forest fires. Geophysical Research Letters 31(18):L18211, doi:10.1029/2004GL020876.

GIRARDIN, M. P. 2007. Interannual to decadal changes in area burned in Canada from 1781-1982 and the relationship to Northern Hemisphere land temperatures. Global Ecology and Biogeography 16:557-566. 
Gray, S. T., J. L. Betancourt, C. L. Fastie, and S. T. Jackson. 2003. Patterns and sources of multidecadal oscillations in drought-sensitive tree-ring records from the central and southern Rocky Mountains. Geophysical Research Letters 30(6):1316; 49-1-4.

Gray, S. T., J. L. Betancourt, S. T. Jackson, and R. G. Eddy. 2006. Role of multidecadal climate variability in a range extension of pinyon pine. Ecology 87:1124-1130.

Gray, S. T., S. T. Jackson, and J. L. Betancourt. 2004. Tree-ring based reconstructions of interannual to decadal scale precipitation variability for northeastern Utah since 1226 A.D. Journal of the American Water Resources Association 40:947-960.

Greenwood, D. L., and P. J. Weisberg. 2008. Density-dependent tree mortality in pinyon-juniper woodlands. Forest Ecology and Management 255:2129-2137.

Hanf, J. M., P. A. Schmidt, and E. B. Groshens. 1994. Sage grouse in the high desert of central Oregon: results of a study, 1988-1993. Portland, OR, USA: US Department of the Interior, Bureau of Land Management, Prineville District. $67 \mathrm{p}$.

HaRDY, C. C. 2005. Wildland fire hazard and risk: problems, definitions, and context. Forest Ecology and Management 211:73-82.

Harris, A. T., G. P. Asner, and M. E. Mlller. 2003. Changes in vegetation structure after long-term grazing in pinyon-juniper ecosystems: integrating imagery spectroscopy and field studies. Ecosystems 6:368-383.

Hessburg, P. F., and J. K. Agee. 2003. An environmental narrative of inland northwest United States forests, 1800-2000. Forest Ecology and Management 178:23-59.

Huffman, D. W., P. Z. Fulé, K. M. Pearson, and J. E. Crouse. 2008. Fire history of pinyon-juniper woodlands at upper ecotones with ponderosa pine forests in Arizona and New Mexico. Canadian Journal of Forest Research 38:2097-2108.

JACOBS, B. F. 2008. Southwestern US juniper savanna and piñon-juniper woodland communities: ecological history and natural range of variability. In: G. J. Gottfried, J. D. Shaw, and P. L. Ford [comPs.]. Ecology, management, and restoration of pinyon-juniper and ponderosa pine ecosystems: combined proceedings of the 2005 St. George, Utah, and 2006 Albuquerque, New Mexico, Workshops. Fort Collins, CO, USA: US Department of Agriculture, Forest Service, Proceedings RMRS-P-51 p. 11-19

JaCoBs, B. F., W. H. Romme, and C. D. Allen. 2008. Mapping old versus young piñon-juniper stands with a predictive topo-climatic model in north-central New Mexico, USA. Ecological Applications 18:1627-1641.

JOHNSEN, T. N. 1962. One-seed juniper invasion of northern Arizona grasslands. Ecological Monographs 32:187-207.

Johnson, D. D., AND R. F. Miller. 2006. Structure and development of expanding western juniper woodlands as influenced by two topographic variables. Forest Ecology and Management 229:7-15.

Johnson, D. D., AND R. F. Miller. 2007. Old-growth juniper: distribution, abundance, and influence on post settlement expansion. Rangeland Ecology and Management 61:82-92.

Kearns, H. S. J., and W. R. JacoBI. 2005. Impacts of black stain root disease in recently formed mortality centers in the piñon-juniper woodlands of southwestern Colorado. Canadian Journal of Forest Research 35:461-471.

KnapP, P. A. 1996. Cheatgrass (Bromus tectorum L.) dominance in the Great Basin desert: history, persistence, and influences of human activities. Global Environmental Change 6:37-52.

KnapP, P. A., AND P. T. SoulÉ. 1996. Vegetation change and the role of atmospheric $\mathrm{CO}_{2}$ enrichment on a relict site in central Oregon: 1960-1994. Annals of the Association of American Geographers 86:387-411.

Knapp, P. A., And P. T. Soulé. 1999. Geographical distribution of an 18th-century heart rot outbreak in western juniper (Juniperus occidentalis var. occidentalis Hook.). Journal of Arid Environments 41:247-256.

Knapp, P. A., And P. T. SoulÉ. 2007. Trends in mid-latitude cyclone frequency and occurrence during fire season in the Northern Rockies: 1900-2004. Geophysical Research Letters 34:L20707, doi:10.1029/2007GL031216.

Knapp, P. A., And P. T. Soulé. 2008. Use of atmospheric $\mathrm{CO}_{2}$-Sensitive trees may influence dendroclimatic reconstructions. Geophysical Research Letters 35:L24703, doi:10.1029/2008GL035664.
Knapp, P. A., P. T. Soulé, and H. D. Grissino-Mayer. 2001. Detecting potential regional effects of increased atmospheric $\mathrm{CO}_{2}$ on growth rates of western juniper. Global Change Biology 7:903-917.

KohleR, T. A., and M. A. Matthews. 1988. Long-term Anasazi land use and forest reduction: a case study from southwest Colorado. American Antiquity 53:537-564

Landis, A. G., AND J. D. Balley. 2005. Reconstruction of age structure and spatial arrangement of piñon-juniper woodlands and savannas of Anderson Mesa, northern Arizona. Forest Ecology and Management 204:221-236.

Leopold, A. 1924. Grass, brush, timber, and fire in southern Arizona. Journal of Forestry 22:2-10.

LEOPOLD, L. 1951. Vegetation of southwestern watersheds in the nineteenth century. Geographical Review 41(2):295-316.

LITTLE, E. L., JR. 1971. Atlas of United States trees, conifers and important hardwoods-volume 1: conifers and important hardwoods. Washington, DC, USA: US Department of Agriculture, Forest Service, Miscellaneous Publications $1146.400 \mathrm{p}$.

Lyford, M. E., S. T. Jackson, J. L. Betancourt, and S. T. Gray. 2003. Influence of landscape structure and climate variability on a late Holocene plant migration. Ecological Monographs 73:567-583.

LyFord, M. E., S. T. Jackson, S. T. Gray, and R. G. Eddy. 2004. Validating the use of woodrat (Neotoma) middens for documenting natural invasions. Journal of Biogeography 31:333-342.

Manier, D. J., N. T. Hobbs, D. M. Theobold, R. M. Reich, M. A. Kalkhan, and M. R. Campbell. 2005. Canopy dynamics and human caused disturbance on a semi-arid landscape in the Rocky Mountains, USA. Landscape Ecology 20:1-17.

McAulifFE, J. R. 2003. The interface between precipitation and vegetation: the importance of soils in arid and semiarid environments. In: J. F. Weltzin and G. R. McPherson [EDS.]. Changing precipitation regimes and terrestrial ecosystems: a North American perspective. Tucson, AZ, USA: University of Arizona Press. p. 9-27.

McPherson, G. R. 1995. The role of fire. In: M. P. McClaran and T. R. Van Devender [EDS.]. The desert grassland. Tucson, AZ, USA: University of Arizona Press. p. 130-151.

Millar, C. I., N. L. Stephenson, and S. L. Stephens. 2007. Climate change and forests of the future: managing in the face of uncertainty. Ecological Applications 17:2145-2151.

Milıer, M. E. 1999. Use of historic aerial photography to study vegetation change in the Negrito Creek watershed, southwestern New Mexico. Southwestern Naturalist 44:121-131.

Miller, R. F., J. D. Bates, T. J. Svejcar, F. B. Pierson, and L. E. Eddleman. 2005. Biology, ecology, and management of western juniper. Corvallis, OR, USA: Oregon State University, Agricultural Experiment Station, Technical Bulletin 152. 77 p.

Miller, R. F., AND J. A. Rose. 1999. Fire history and western juniper encroachment in sagebrush steppe. Journal of Range Management 52:550-559.

MilleR, R. F., and R. J. Tausch. 2001. The role of fire in juniper and pinyon woodlands: a descriptive analysis. In: K. M. Galley and T. P. Wilson [EDS.]. Proceedings of the Invasive Species Workshop: the role of fire in the control and spread of invasive species-Fire Conference 2000: The First National Congress on Fire Ecology, Prevention, and Management; 27 November-1 December 2000; San Diego, CA, USA. Tallahassee, FL, USA: Tall Timbers Research Station, Miscellaneous Publication 11. p. 15-30.

Miller, R. F., R. J. Tausch, E. D. McArthur, D. J. Johnson, and S. C. Sanderson. 2008. Age structure and expansion of piñon-juniper woodlands: a regional perspective in the Intermountain West. Fort Collins, CO, USA: US Department of Agriculture, Forest Service, Rocky Mountain Research Station, Research Paper RMRS-RP-69. $15 \mathrm{p}$.

Miller, R. F., and P. E. Wigand. 1994. Holocene changes in semiarid pinyon-juniper woodlands. BioScience 44:465-476.

MitcheLL, V. 1976. The regionalization of climate in the western United States. Journal of Applied Meteorology 15:920-927.

Moore, D. J., R. S. Nowak, and R. J. TAusch. 1999. Gas exchange and carbon isotope discrimination of Juniperus osteosperma and Juniperus occidentalis across environmental gradients in the Great Basin of western North America. Tree Physiology 19:421-433 
Morino, K., C. H. Baisan, and T. W. Swetnam. 1998. Expanded fire regime studies in the Jemez Mountains, New Mexico. Los Alamos, NM, USA: National Biological Service, Bandelier National Monument, Final Report. 94 p. (Unpublished report on file at US Geological Survey.)

Mueller, R. C., C. M. Scudder, M. E. Porter, R. T. Trotter, III, C. A. Gehring, and T. G. Whiтнам. 2005. Differential tree mortality in response to severe drought: evidence for long-term vegetation shifts. Journal of Ecology 93:13652745.

Muldavin, E., C. Baisan, T. Swetnam, L. Delay, and K. Morino. 2003. Woodland fire history studies in the Oscura and northern San Andres Mountains, White Sands Missile Range, New Mexico: final report to White Sands Missile Range. White Sands Missile Range, NM, USA: WSMR Document 92F018. 35 p.

Neilson, R. P. 1986. High-resolution climatic analysis and southwest biogeography. Science 232(4746):27-34.

Ni, F., T. Cavazos, M. K. Hughes, A. C. Comrie, and G. Funkhouser. 2002. Cool-season precipitation in the southwestern USA since AD 1000: comparison of linear and nonlinear techniques for reconstruction. International Journal of Climatology 22:1645-1662.

Nowak, C. L., R. S. Nowak, R. J. Tausch, and P. E. Wigand. 1994. Tree and shrub dynamics in northwestern Great Basin woodland and shrub steppe during the Late-Pleistocene and Holocene. American Journal of Botany 81:265-277.

Nowak, R. S., D. J. Moore, and R. J. Tausch. 1999. Ecophysiological patterns of pinyon and juniper. In: S. B. Monsen, R. Stevens, R. J. Tausch, R. Miller, and S. Goodrich [EDS.]. Proceedings of Ecology and Management of PinyonJuniper Communities within the Interior West; 15-18 September 1997; Provo, UT, USA. Ogden, UT, USA: US Department of Agriculture, Forest Service. Proceedings RMRS-P-9. p. 35-46.

OLIPHANT, J. 0. 1968. On the cattle ranges of the Oregon country. Seattle, WA, USA: University of Washington Press. 372 p.

Paulson, D. D., and W. L. Baker. 2006. The nature of southwestern Colorado. Boulder, CO, USA: University Press of Colorado. 386 p.

PYNE, S. J. 1982. Fire in America: a cultural history of wildland and rural fire. Princeton, NJ. USA: Princeton University Press. 654 p.

Ramsey, D. 2003. Soils of Mesa Verde country. In: M. L. Floyd [Ed.]. Ancient piñonjuniper woodlands. Boulder, CO, USA: University Press of Colorado. p. 213-222.

ReED, J. R. 2006. A note on fire frequency and definitions. Canadian Journal of Forest Research 36:1884-1888.

Romme, W., C. Allen, J. Bailey, W. Baker, B. Bestelmeyer, P. Brown, K. Eisenhart, L. Floyd-Hanna, D. Huffman, B. Jacobs, R. Miller, E. Muldavin, T. Swetnam, R. TAusch, And P. Weisberg. 2007. Historical and modern disturbance regimes of piñon-juniper vegetation in the western US. Tallahassee, FL, USA: Nature Conservancy, Fire Learning Network. 13 p. [a short version of Romme et al. 2008]

Romme, W., C. Allen, J. Balley, W. Baker, B. Bestelmeyer, P. Brown, K. Eisenhart, L. Floyd-Hanna, D. Huffman, B. Jacobs, R. Miller, E. Muldavin, T. Swetnam, R. TAUSCH, AND P. WeISBERG. 2008. Historical and modern disturbance regimes of piñon-juniper vegetation in the western US. Fort Collins, CO, USA: Colorado Forest Restoration Institute, Colorado State University. 27 p. Available at: http://www.cfri.colostate.edu/.

Sallach, B. K. 1986. Vegetation changes in New Mexico documented by repeat photography [thesis]. Las Cruces, NM, USA: New Mexico State University. $68 \mathrm{p}$.

Samuels, M. L., and J. L. Betancourt. 1982. Modeling the long-term effects of fuelwood harvests on pinyon-juniper woodlands. Environmental Management 6:505-515.

Schmidt, K. M., J. P. Menakis, C. C. Hardy, W. J. Hann, and D. L. Bunnell. 2002. Development of coarse-scale spatial data for wildland fire and fuel management. Washington, DC, USA: US Department of Agriculture, Forest Service, General Technical Report RMRS-87. 41 p.

Schoennagel, T., T. T. Veblen, and W. H. Romme. 2004. The interaction of fire, fuels, and climate across Rocky Mountain forests. BioScience 54:661-676.

Schroeder, M. A., and L. A. RobB. 2004. Fidelity of greater sage-grouse Centrocercus urophasianus to breeding areas in a fragmented landscape. Wildlife Biology 9:291-299.
ScURLOCK, D. 1998. From the Rio to the Sierra: an environmental history of the Middle Rio Grande Basin. Washington, DC, USA: US Department of Agriculture, Forest Service, General Technical Report RMRS-GTR-5. 440 p.

SelBy, D. 2005. Assessing pinyon pine mortality on the Uncompahgre Plateau in western Colorado, USA [thesis]. Fort Collins, CO, USA: Colorado State University. $79 \mathrm{p}$.

Shaw, J. D., B. E. Steed, and L. T. Deblander. 2005. Forest inventory and analysis (FIA) annual inventory answers the question: what is happening to pinyonjuniper woodlands? Journal of Forestry 103(6):280-285.

ShinNEMAN, D. J., AND W. L. BAKER. 2009. Historical fire and multidecadal drought as context for piñon-juniper woodland restoration in western Colorado. Ecological Applications (in press).

SoulÉ, P. T., AND P. A. Knapp. 1999. Western juniper expansion on adjacent disturbed and near-relict sites. Journal of Range Management 52:525-533.

Soulé, P. T., And P. A. Knapp. 2000. Juniperus occidentalis (western juniper) establishment history on two minimally disturbed research natural areas in central Oregon. Western North American Naturalist 60:26-33.

SoulÉ, P. T., AND P. A. Knapp. 2007. Topoedaphic and morphological complexity of foliar damage and mortality within western juniper (Juniperus occidentalis var. occidentalis) woodlands following an extreme meteorological event. Journal of Biogeography 34:1927-1937.

Soulé, P. T., P. A. Knapp, and H. D. Grissino-Mayer. 2003. Comparative rates of western juniper afforestation in south-central Oregon and the role of anthropogenic disturbance. Professional Geographer 55:43-55.

Soulé, P. T., P. A. Knapp, and H. D. Grissino-Mayer. 2004. Human agency, environmental drivers, and western juniper establishment during the late Holocene. Ecological Applications 14:96-112.

SpRingfield, H. W. 1976. Characteristics and management of southwestern pinyon-juniper ranges: the status of our knowledge. Fort Collins, CO, USA: US Department of Agriculture, Forest Service, Research Paper RM-160.

Swetnam, T. W., C. D. Allen, and J. L. Betancourt. 1999. Applied historical ecology: using the past to manage for the future. Ecological Applications 9:1189-1206.

Swetnam, T. W., and J. L. Betancourt. 1998. Mesoscale disturbance and ecological response to decadal climatic variability in the American southwest. Journal of Climate 11:3128-3147.

Swetnam, T. W., and P. M. Brown. 1992. Oldest known conifers in the Southwestern United States: temporal and spatial patterns of maximum age. In: M. R. Kaufmann, W. H. Moir, and R. L. Basset [TECH. EDS.]. Old-growth forests in the Southwest and Rocky Mountain regions, proceedings of a workshop; 9-11 March 1992; Portal, AZ, USA. Fort Collins, CO, USA: US Department of Agriculture, Forest Service, GTR-RM-213. p. 24-38.

Waichler, W. S., R. F. Miller, and P. S. Doescher. 2001. Community characteristics of old-growth western juniper woodlands in the pumice zone of central Oregon. Journal of Range Management 54:518-527.

Wangler, M. J., and R. A. Minnich. 1996. Fire and succession in pinyon-juniper woodlands of the San Bernardino Mountains, California. Madroño 43:493-514.

Weisberg, P. J., D. Ko, C. Py, and J. M. Bauer. 2008. Modeling fire and landform influences on the distribution of old-growth pinyon-juniper woodland. Landscape Ecology 23:931-943.

Weisberg, P. J., E. Lingua, and R. B. Pillal. 2007. Spatial patterns of pinyon-juniper expansion in central Nevada. Rangeland Ecology and Management 60:115-124.

Westerling, A. L., H. D. Hidalgo, D. R. Cayan, and T. W. Swetnam. 2006. Warming and earlier spring increase western US forest wildfire activity. Science 313:940-943.

Whisenant, S. G. 1990. Changing fire frequencies on Idaho's Snake River Plains: ecological and management implications. In: E. D. McArthur, E. M. Romney, S. D. Smith, and P. T. Tueller [Comps.]. Proceedings of the Symposium on Cheatgrass Invasion, Shrub Die-Off, and Other Aspects of Shrub Biology and Management; 5-7 April 1989; Las Vegas, NV, USA. Ogden, UT, USA: US Department of Agriculture, Forest Service, Intermountain Research Station, General Technical Report INT-276. p. 4-10. 
Wigand, P. E., and D. Rhode. 2002. Great basin vegetation history and aquatic systems: the last 150,000 years. In: R. Hershler, D. B. Madsen, and D. R. Currey [EDS.]. Great Basin aquatic systems history. Washington, DC, USA: Smithsonian Institution Press, Smithsonian contributions to earth sciences 33. p. 309-367.

WILKINSON, M. C. 1997. Reconstruction of historical fire regimes along an elevation and vegetation gradient in the Sacramento Mountains, New Mexico. [thesis]. Tucson: AZ, USA: University of Arizona. 128 p.

Wooton, E. 0. 1908. The range problem in New Mexico. Las Cruces, NM, USA: College of Agriculture and Mechanic Arts (New Mexico State University), Agriculture Experiment Station Bulletin 66. 46 p.
WriGHT, H. A. 1980. The role and use of fire in the semidesert grassland type. Ogden, UT, USA: US Department of Agriculture, Forest Service, General Technical Report INT-85. $24 \mathrm{p}$

Wullschleger, S. D., T. J. TSchaplinski, and R. J. Norby. 2002. Plant water relations at elevated $\mathrm{CO}_{2}$-implications for water-limited environments. Plant, Cell and Environment 25:319-331.

Wyckoff, D. G. 1977. Secondary forest succession following abandonment of Mesa Verde. Kiva 42(3-4):215-231.

Young, J. A., AND J. D. Budy. 1979. Historical use of Nevada's pinyon-juniper woodlands. Journal of Forest History 23:112-121. 